Citation: Tânia Gonçalves, João Rebelo, Lina Lourenço-Gomes, José Caldas (2021) Wine price determinants. Is there a homogeneous international standard? Wine Economics and Policy 10(1): 33-55. doi: 10.36253/wep-8879

Copyright: @2021 Tânia Gonçalves, João Rebelo, Lina Lourenço-Gomes, José Caldas. This is an open access, peerreviewed article published by Firenze University Press (http://www.fupress. com/wep) and distributed under the terms of the Creative Commons Attribution License, which permits unrestricted use, distribution, and reproduction in any medium, provided the original author and source are credited.

Data Availability Statement: All relevant data are within the paper and its Supporting Information files.

Competing Interests: The Author(s) declare(s) no conflict of interest.

\section{Wine price determinants. Is there a homogeneous international standard?}

\author{
Tânia Gonçalves*, João Rebelo, Lina Lourenço-Gomes, José Caldas \\ University of Trás-os-Montes and Alto Douro, Quinta de Prados, 5001-801 Vila Real, \\ Portugal \\ E-mail: tgoncalves@utad.pt; jrebelo@utad.pt; lsofia@utad.pt; jcaldas@utad.pt \\ *Corresponding author.
}

\begin{abstract}
This article presents an international comparison of the main determinants of wine prices in specialist online wine shops. Hedonic price functions were estimated for 9624 wines spread among four datasets from France, Italy, Germany and Australia. To explain price variation data was collected on wine classification, closure type, wine origin, medals or awards, vintage, alcohol content, color, and grape variety. Results from quantile regression models show that the wine vintage is a common price driver in all markets and quantiles. A quite similar effect was found for alcohol content. In terms of color, the implicit prices for red and white wines are also structurally different between countries, particularly in origin, blend, closure, awards and age. Thus, the markets should be assumed as heterogeneous, and the extrapolation of the results from one market to another may lead to erroneous management decisions.
\end{abstract}

Keywords: country-based comparison, hedonic analysis, pricing, quantile regression models, specialist retailer prices.

\section{INTRODUCTION}

Inherent to globalization, in the last two decades, the wine industry has undergone profound changes, highlighting the entrance of new firms in the international market, especially from new producing countries, the decrease in wine consumption in traditional ones, and changes in consumer habits and behavior. Wine is increasingly becoming an experience and complex good, with different and new attributes valued by the consumer, driving the wineries to reconfigure their behavior and the type of wine to be produced to be successful in the market [43]. The change in consumer profile is reflected in the requirement of more and better information, access to new communication technologies, the way and the time to make purchasing and consumption decisions, leading to choices based on attributes such as the type of wine, age, grape variety, color, geographical origin, expert and consumer opinion, and price.

Therefore, price is a core component in both wineries and consumers' decision-making process, being the relationship between wine price and its 
determinants a widely addressed topic in the wine economics literature [42]. Since the wine market is characterized by a large number of firms with different sizes and supplying different wines, the wines' prices are not only affected by the quantity demanded but most importantly by a set of attributes considered by consumers. In light of this finding, the wine prices are typically studied using a hedonic pricing model based on Lancaster's approach, which associates the price of a good to its various objective and subjective attributes or characteristics taken by consumers when facing a buying decision.

The main theoretical foundation of the hedonic price function studies comes from Rosen's [45] pure competition model for differentiated products, which assumes that the demand and supply for attributes interact to determine the implicit marginal attribute market prices. The empirical application of the hedonic price theory in the wine industry started in the early 1990s. It remains a widely used methodology, whose findings are most relevant in wine marketing [e.g.2,4,6,10,15,16,26,28 ,32,37,41,42,44,46,49,51].

In general, the estimation of a hedonic price function comprises three main types of explanatory variables. Firstly, the so-called objective attributes, such as color, vintage, alcohol content and grape variety, which tend to be detailed on the label and are therefore easy to identify $[15,16,20,32,33,34,46,49]$. Secondly, the sensory attributes, such as aroma, finish or harmony, information that usually comes from expert opinions (ratings) or medals awarded $[8,9,11,25,28,35,41,48]$. Finally, the third category of variables addresses the influence of reputation, both individual and collective, of wines and producers amongst consumers. The individual reputation is essentially based on the producer and own brand, while the collective reputation refers to variables such as umbrella brand, geographic origin, wine classification (e.g. reserve) and the type of producer $[5,10,14,22,23,31$, $32,36,38,39$.

A recent study by [42] ${ }^{1}$ offers a thorough classification of all the determinants of wine prices, using a hedonic framework, developed by the academic research (117 papers published) between 1993 and 2018. In addition to the determinants referred above as objective and sensory attributes, included in their classification as "public information" price determinants (informa-

\footnotetext{
${ }^{1}$ The review is organized according to four main categories of wine price determinants: geographical and agricultural factors (weather/climate, soil and terroir, region of origin/appellation/grape varieties); temporal factors (age and vintage year); public information (information on the label, information given by experts or rating agencies and the causality between perceived quality and revealed prices); the impact of supply on wine prices (producer size or quantity produced, production costs).
}

tion on the label, information given by experts or rating agencies), these authors also emphasized the importance of other determinants such as weather/climate $[3,7,24,26,28,54]$ or the supply for wine $[17,26,40,46,50]$. Ashenfelter et al. [3] found that increasing the temperature of $1{ }^{\circ} \mathrm{C}$ results in a price increase of $61.6 \%$ of Bordeaux Grands Cru, a result confirmed by Jones and Storchmann [28] for the Bordeaux wine region. More recently Ashenfelter and Storchmann [7] presented a notable review of the economic implications of climate change on wine prices. Additionally, focusing on how wine supply impacts wine prices, and considering the quantity supplied as a significant determinant of prices, some studies have shown that the impact on prices is positive for small wineries and negative for the largest ones [40,46]. Moreover, other studies, where the quantity supplied is measured by the number of cases of wine or the number of bottles produced $[17,26,50]$, seem to indicate that both the quantity produced and the producer size hurt prices.

Considering the increasing heterogeneity of the wine in the markets as well as in the distribution channels, the analysis of the price determinants has been extended to price segments and distribution channels $[1,12,18,45]$, including the on-line or e-commerce channel. For example, using a hedonic price approach for the Portuguese wine market, drawing on data from a specialist retailer and a large supermarket, the recent study of [45] found that the significance of the various price determinants differs between distribution channels.

The online or e-commerce channel is growing and gaining market share [44] against the traditional distribution, which constitutes a challenge, but also an opportunity for wineries, namely for the small and medium ones.

Moreover, assuming that the wine price determinants do not vary according to wine color, several studies on wine pricing literature mentioned above include an analysis of wine in a broad sense (comprising both white and red wine). However, for specific characteristics, this hypothesis may be unsuitable [17], and in fact, recent studies corroborate the assumption that some attributes perform differently for red and white wines [e.g., 13]. For this reason, there is a trend to a market segmentation based on red versus white wine [52], which leads us to the estimation of different hedonic functions depending on color, in the cases under study.

Even though the empirical studies typically use data from a specific country market, there is a trend towards the generalization and conveyance of the results from certain markets to other markets. This is a strong assumption that should be tested since it neglects the heterogene- 
ity of international markets, preferences, and behavior of consumers. In other words, a better understanding and generalization of the empirical results raise the issue of homogeneity of wine price determinants not only between different price-segments but also among different countries, driving to the research question of this paper of whether the results for one market are transferable to other markets. Thus, the main contribution of this paper is to strengthen the empirical knowledge on the determinants of wine price, in general, and for red and white wines, in particular, and to point clues for more detailed knowledge of the consumer preferences.

Following the mainstream of the literature and based on the hedonic price approach ${ }^{2}$ we analyze the wine price determinants in different countries (Australia, Germany, France and Italy) using the same data structure, a specialist online wine shop in each country. These four countries are all large producers/consumers' countries, three of them, France, Germany and Italy, are regarded as "Old World wine countries", while the remaining one, Australia, is included in the "New World wine countries".

The paper is organized as follows. The second section presents the material and method used, providing details about the data sources and the model applied. The third section includes the results, where these are presented for the whole sample of still wine (pooled data) and for subsamples of red and white wines, for each country. Finally, section four concludes the paper.

\section{MATERIAL AND METHODS}

\subsection{Data}

The four countries referred above were selected according to their importance on the world wine industry, both in terms of their production and consumption. In 2018 (OIV, 2019), regarding world production (in volume) Italy ranks the first place, France the second, Australia the ninth and Germany the tenth. Concerning world consumption, also in volume, France ranks the second place, Italy the third, Germany the fourth and Australia the tenth. In France, almost $83 \%$ of the consumption is covered by domestic wine [53] where a large share is sold as PDO (Protected Designation of Origin) and PGI (Protected Geographic Indication). Similarly, in Italy, almost $95 \%$ of the wine consumed comes from the domestic market [1] and it is mainly sold under the PDO

\footnotetext{
2 Since our aim is to compare information that is homogeneous within the sample, the terroir attribute is not included due to its specificity in location, and thus varying from country to country.
}

and PGI classifications. The Australian market is almost $90 \%$ supplied by domestic production, with a growing dominance of supermarket distribution and increased relevance of online sales [29]. Contrary to Australia, France, and Italy, which are big wine exporters, in Germany imports represent almost 50\% of the domestic wine consumption, and sales are $85 \%$ off-premise and $15 \%$ on-premise [19].

Different sources of wine prices have been used in the literature [21], namely the suggested prices, as published in prominent guides; en primeur prices obtained from broker houses; retailed prices reported in consumer or websites, obtained through the direct survey, or gathered by private data provider such as Nielsen; auction prices; and restaurant prices. The choice of the data source seems to depend both on the goal of the study and data availability and can influence the results and its economic interpretation. In this research, we focus on specialist retailers (wine stores) in each market, selling through brick-and-mortar outlets and online, as a representative part of the off-trade more sophisticated retailers, compared to supermarkets. We consider these specialty stores as they generally are more selective in their wines and carry wines in more price segments. A preliminary survey on wine forums and wine news was carried out to identify wine stores in each country under analysis.

Therefore, four databases, in a total of 9624 bottled wines, were used to achieve the intended goals of this study. French data were retrieved from "Vinatis" online shop, www.vinatis.com, with 2094 observations after refinements on outliers' detection. Data for Italy were collected from "XtraWine", www.xtrawine.com, comprising 2803 observations. Data for Australian market were collected from "Vintage Cellars" online shop, www. vintagecellars.com.au, which gave a total of 2063 observations. Finally, data for Germany were collected from "Vinexus", www.vinexus.de, with 2664 observations. The period for data collection was from May 22 to October 27, 2019.

A first glance of the sites indicates that the information is more detailed by French and Italian wineries than by the Australian and German ones. The French site highlights the type, country, region, appellation, grape variety, color, price, award, alcohol, style, and store instructions. The Italian market reports about the type, origin (zone), award, producer, appellation, price, and food matching. The Australian site features the country, brand, region, and price range, while Germany includes type, country, region and variety. In summary, based on the assumption that the information provided by stores is demand-driven, we can conclude that consumers in tra- 
Table 1. Variables included in the analysis.

\begin{tabular}{|c|c|}
\hline Variables & Description \\
\hline Price & Continuous variable expressed in euros \\
\hline Classification & $\begin{array}{l}1 \text { if the wine is classified as Reserve/Grand } \\
\text { Reserve } \\
0 \text { otherwise }\end{array}$ \\
\hline Closure & $\begin{array}{l}1 \text { if the wine has a cork cap } \\
0 \text { if screw cap }\end{array}$ \\
\hline Wine origin & $\begin{array}{l}1 \text { if the wine is a national production } \\
0 \text { otherwise }\end{array}$ \\
\hline Medals/Awards & $\begin{array}{l}1 \text { if the wine is an awarded wine } \\
0 \text { otherwise }\end{array}$ \\
\hline Age & Continuous variable \\
\hline Alcohol & Continuous variable \\
\hline Color & $\begin{array}{l}1 \text { if red wine } \\
0 \text { otherwise }\end{array}$ \\
\hline \multicolumn{2}{|l|}{ Grape } \\
\hline Blend & $\begin{array}{l}1 \text { if the wine is Blended } \\
0 \text { otherwise }\end{array}$ \\
\hline Cabernet Sauvignon & $\begin{array}{l}1 \text { if the grape varietal is } 100 \% \text { Cabernet } \\
\text { Sauvignon } \\
0 \text { otherwise }\end{array}$ \\
\hline Syrah & $\begin{array}{l}1 \text { if the grape varietal is } 100 \% \text { Syrah } \\
0 \text { otherwise }\end{array}$ \\
\hline Other Red & $\begin{array}{l}1 \text { if the wine has another red varietal } \\
0 \text { otherwise }\end{array}$ \\
\hline Sauvignon Blanc & $\begin{array}{l}1 \text { if the grape varietal is } 100 \% \text { Sauvignon } \\
\text { Blanc } \\
0 \text { otherwise }\end{array}$ \\
\hline Chardonnay & $\begin{array}{l}1 \text { if the grape varietal is } 100 \% \text { Chardonnay } \\
0 \text { otherwise }\end{array}$ \\
\hline Other white & $\begin{array}{l}1 \text { if the wine has another white varietal } \\
0 \text { otherwise }\end{array}$ \\
\hline
\end{tabular}

ditional markets (France and Italy), seem to be looking for more complex information, although in all of them there is common information, such as the type of wine, the brand, and region. However, a more robust and incisive analysis is needed to verify whether the information presented is relevant for price formation in each market and whether its effects are similar within markets, taking also into account the segmentation by color.

Thus, accordingly to the literature review and constrained by the information collected the price explanatory variables used in this paper are a drawn on objective attributes (alcohol content, wine age, grape varieties, wine color), sensory attributes as the result of medals or awards won (rating by experts), and reputation (wine origin - imported or domestic, wine classification as Reserve/Grand Reserve, and closure type - cork or screw cap). The price (explained variable) is expressed in euros per bottle with a standard $75 \mathrm{cl}$ size. In order to reduce heterogeneity, a natural log is applied to the price. Table
1 includes the description of the variables used in the hedonic price function.

Table 2 includes a summary of the descriptive statistics for the variables included in the estimation of the hedonic price function and Appendix A includes the Phi correlation between binary variables in each country. This coefficient shows that, in general, the variables are not correlated or show a very low degree of correlation, except for a positive correlation between medals and cap type in the Italian market, which means that an awarded wine is associated with a cork cap. Additionally, in Australia, we found a negative correlation between wine origin and closure type, which suggests that domestic wine is negatively associated with cork cap, and positively with screw cap closure.

Regarding the descriptive statistics, the average alcohol level is similar in the four markets (between 13\% and $14 \%$ ), with a high concentration around the average (Coefficient of variation ${ }^{3}$ or $\mathrm{CV}$ of $6 \%$ and $7 \%$ ). The average age (vintage) is also similar, around 4 years, being slightly higher in Italy, although there is a higher relative dispersion in Australia, a CV of 97\%, against 51\% in France and $47 \%$ in Germany and Italy. Relatively to the behavior of the explanatory discrete variables we have to emphasize that: there is a predominance of red wine, especially in Germany ( $82 \%$ of observations); the awards or medals are relevant in Europe, especially in France and Italy ( $81 \%$ and $72 \%$ of the sample, respectively); in the producing countries (Australia, France, and Italy) the supply is mainly characterized by domestic wines, while in Germany it only represents $14 \%$ of this feature; cork stoppers predominate in the traditional producer and consumer countries (97\% in France and 70\% in Italy), being only $17 \%$ in Australia and 38\% in Germany; the "reserve" label appears as irrelevant in any of the markets; and in terms of grape varieties, the blend has more expression in France (46\%), followed by Italy (31\%). Single varietals (Cabernet Sauvignon, Syrah and Chardonnay) have more prominence in Australia, with Chardonnay having some weight in France (10\%) and Germany (9\%).

The average price is roughly €22 in Germany, €32 in Italy, $€ 35$ in Australia and $€ 44$ in French, with dispersion around the average of $96 \%, 120 \%, 189 \%$ and $148 \%$, respectively. The average price of red wine is substantially higher than that of white wine, except in Italy. Considering the supply structure by price segments, as we can observe in Figures 1 and 2, the German retailer has the highest share of wine bottles in the lowest class (up to $10 €$ ), $27 \%$ of the total. Moreover, close to $70 \%$ of its wines on sale cost up to $€ 20$ and $83 \%$ cost up to $€ 30$.

${ }^{3}$ Coefficient of variation, which shows the extent of variability in rela- 
Table 2. Descriptive statistics.

\begin{tabular}{|c|c|c|c|c|c|c|c|c|c|c|c|c|c|c|c|c|}
\hline \multirow{3}{*}{ Variable } & \multicolumn{16}{|c|}{ Specialist shop } \\
\hline & \multicolumn{4}{|c|}{$\begin{array}{c}\text { Vintage Cellars - } 2063 \\
\text { observations } \\
\text { Australia }\end{array}$} & \multicolumn{4}{|c|}{$\begin{array}{c}\text { Vinexus - } 2664 \\
\text { observations } \\
\text { Germany }\end{array}$} & \multicolumn{4}{|c|}{$\begin{array}{l}\text { Vinatis - } 2094 \\
\text { observations } \\
\text { France }\end{array}$} & \multicolumn{4}{|c|}{$\begin{array}{c}\text { XtraWine - } 2803 \\
\text { observations } \\
\text { Italy }\end{array}$} \\
\hline & Mean & $\mathrm{CV}$ & Min & $\operatorname{Max}$ & Mean & $\mathrm{CV}$ & Min & Max & Mean & $\mathrm{CV}$ & Min & Max & Mean & $\mathrm{CV}$ & Min & Max \\
\hline $\begin{array}{l}\text { Wine price (euro) } \\
\text { (Median) }\end{array}$ & $\begin{array}{c}35.28 \\
(16.11)\end{array}$ & 1.89 & 2.48 & 576.59 & $\begin{array}{l}21.85 \\
(14.9)\end{array}$ & 0.96 & 4.2 & 200 & $\begin{array}{l}43.63 \\
(21.9)\end{array}$ & 1.48 & 5.9 & 530 & $\begin{array}{l}32.69 \\
(20.0)\end{array}$ & 1.20 & 5.06 & 378.81 \\
\hline Red wine price & 44.19 & 1.79 & 2.48 & 576.59 & 22.5 & 0.97 & 4.2 & 200 & 50.0 & 1.41 & 5.9 & 530 & 32.9 & 1.19 & 5.06 & 378.20 \\
\hline White wine price & 17.05 & 0.89 & 3.34 & 154.99 & 19.1 & 0.87 & 4.6 & 179 & 33.0 & 1.56 & 6 & 470 & 32.4 & 1.21 & 5.86 & 378.81 \\
\hline Alcohol Content (AlcCont) & 13.50 & 0.07 & 9 & 16.5 & 13.39 & 0.07 & 9.5 & 16.5 & 13.44 & 0.06 & 9 & 17 & 13.59 & 0.06 & 9 & 17 \\
\hline \multirow[t]{2}{*}{ Age } & 3.93 & 0.97 & 1 & 69 & 3.99 & 0.47 & 1 & 23 & 3.94 & 0.51 & 1 & 50 & 4.61 & 0.47 & 2 & 23 \\
\hline & Prop.1 & & & & Prop. 1 & & & & Prop.1 & & & & Prop.1 & & & \\
\hline $\begin{array}{l}\text { Color } \\
(\text { Red=1; White+Rosé }=0)\end{array}$ & 0.67 & & & & 0.82 & & & & 0.64 & & & & 0.56 & & & \\
\hline $\begin{array}{l}\text { Awards or medals } \\
(\text { yes }=1 ; \text { no }=0)\end{array}$ & 0.14 & & & & 0.51 & & & & 0.81 & & & & 0.72 & & & \\
\hline \multicolumn{17}{|l|}{ Wine origin } \\
\hline (national $=1 ;$ imported $=0$ ) & 0.75 & & & & 0.14 & & & & 0.90 & & & & 0.77 & & & \\
\hline $\begin{array}{l}\text { Closure } \\
(\text { cork }=1 ; \text { screw cap }=0)\end{array}$ & 0.17 & & & & 0.38 & & & & 0.97 & & & & 0.70 & & & \\
\hline Reserve $($ yes $=1 ;$ no= $=0$ ) & 0.01 & & & & 0.04 & & & & 0.02 & & & & 0.07 & & & \\
\hline \multicolumn{17}{|l|}{ Grape } \\
\hline $\begin{array}{l}\text { Blend } \\
\text { (yes=1; no=0) }\end{array}$ & 0.05 & & & & 0.12 & & & & 0.46 & & & & 0.31 & & & \\
\hline $\begin{array}{l}\text { Cabernet Sauvignon } \\
(\text { yes }=1 ; \text { no }=0)\end{array}$ & 0.15 & & & & 0.06 & & & & 0.01 & & & & 0.01 & & & \\
\hline $\begin{array}{l}\text { Syrah } \\
(\text { yes }=1 ; \text { no=0) }\end{array}$ & 0.28 & & & & 0.04 & & & & 0.08 & & & & 0.01 & & & \\
\hline $\begin{array}{l}\text { Other Red } \\
(\text { yes }=1 ; \text { no }=0)\end{array}$ & 0.20 & & & & 0.61 & & & & 0.23 & & & & 0.32 & & & \\
\hline $\begin{array}{l}\text { Sauvignon Blanc } \\
(\text { yes }=1 ; \text { no }=0)\end{array}$ & 0.08 & & & & 0.07 & & & & 0.02 & & & & 0.04 & & & \\
\hline $\begin{array}{l}\text { Chardonnay } \\
(\text { yes }=1 ; \text { no }=0 \text { ) }\end{array}$ & 0.11 & & & & 0.09 & & & & 0.10 & & & & 0.05 & & & \\
\hline $\begin{array}{l}\text { Other white } \\
\text { (yes }=1 ; \text { no }=0 \text { ) }\end{array}$ & 0.13 & & & & 0.01 & & & & 0.11 & & & & 0.25 & & & \\
\hline
\end{tabular}

Note: Prop. $1=$ proportion of 1

Only $1 \%$ cost more than $€ 100$. Comparatively, the Australian retailer has a lower percentage of low-price wine (16\%), exhibiting the majority of its bottles (60\%) a cost up to $€ 20$. In this retailer, the more expensive wines represent $6 \%$ of the total. Distinctly, the French winery has the highest proportion of high-priced wines (8\%, above $€ 100)$ and the lowest proportion of cheap wines $(12 \%$, up to $10 €)$. Despite the lower proportion of more expensive wines (5\%), the price structure of the Italian wines tends to be closer to the French one.

Overall, this analysis shows that the indication provided by the average prices is aligned with the finer analysis given by price segments, suggesting that the price structure is not identical between the wine cellars, which reinforces the relevance of investigating its determinants for price quantiles.

\subsection{Method}

The traditional linear regression models describe the average relationship between a set of explanatory variables and the dependent variable, based on the conditional mean function. However, this approach may 


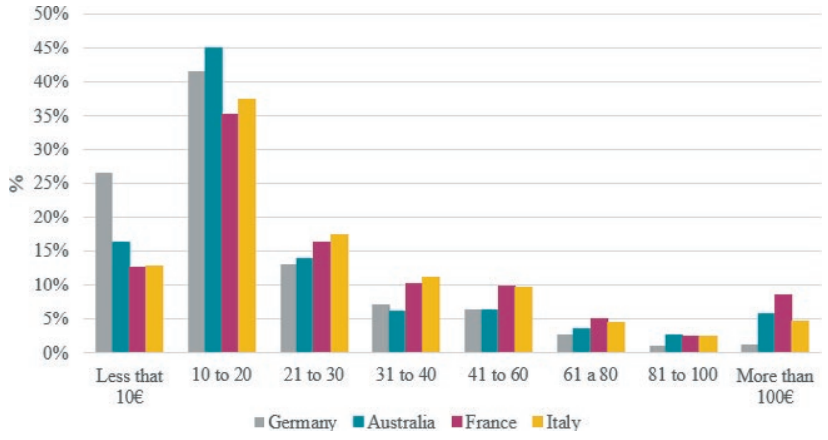

Figure 1. Wine price segments.

provide only a partial view of this relationship, where we can only focus on different points of the conditional distribution. For his reason, quantile regression models have been a useful and popular alternative to the tradi-

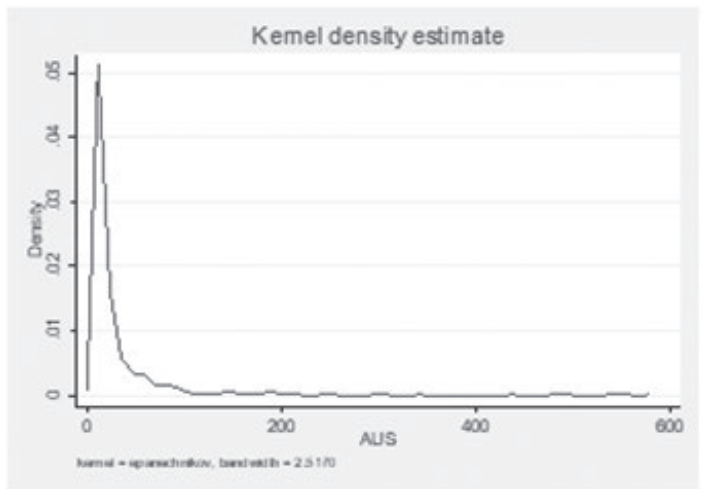

\section{Australia}

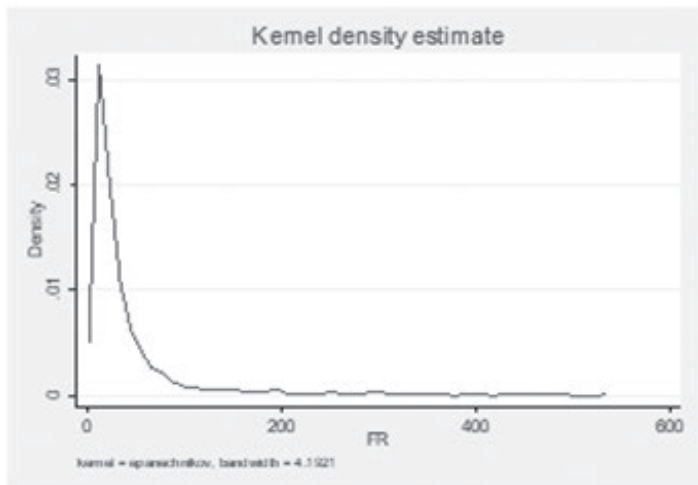

France

Figure 2. Kernel density estimate for Price. tional linear regression models. Introduced by [30], these models provide appropriated modelling in the presence of different parts of the conditional response distribution changing at different rates. The quantile regression model for $\mathrm{Q}_{\mathrm{Y}}(\tau \mid x)$, at the $\tau$ th quantile of $\mathrm{Y}$ given a vector of covariates $\mathrm{X}=x$ is:

$\mathrm{Q}_{\mathrm{Y}}(\tau \mid x)=\beta_{0}(\tau)+\beta_{1}(\tau) x_{i 1}+\cdots+\beta_{p}(\tau) x_{i p}, i=1, \ldots, n$

being $\beta_{0}(\tau)$ the scalar intercept and $\tau \in(0,1) . \beta(\tau)$ are estimated by solving the following minimization problem:

$\min _{\beta(\tau)} \sum_{i=1}^{n} \rho_{\tau}\left(y_{i}-\beta_{0}(\tau)-\sum_{j=1}^{p} x_{i j} \beta_{j}(\tau)\right)$

where $\rho_{\tau}(r)=\tau \max (r, 0)+(1-\tau) \max (-r, 0)$ is referred to as the check loss. The solution to the minimization problem estimates different regression curves for various points of the distribution and yields distinct sets of

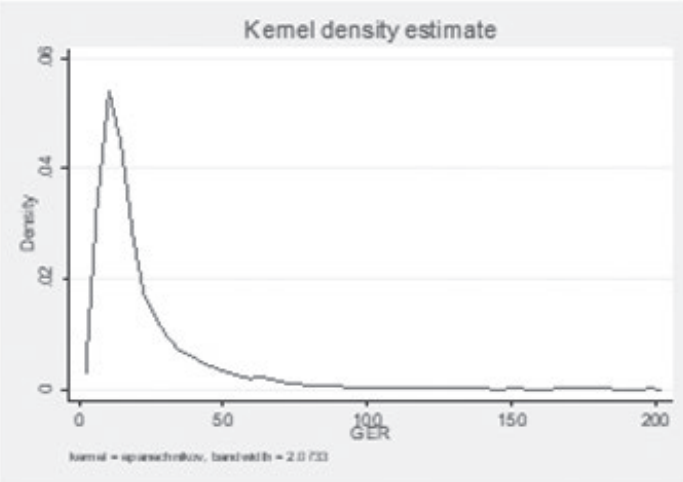

Germany

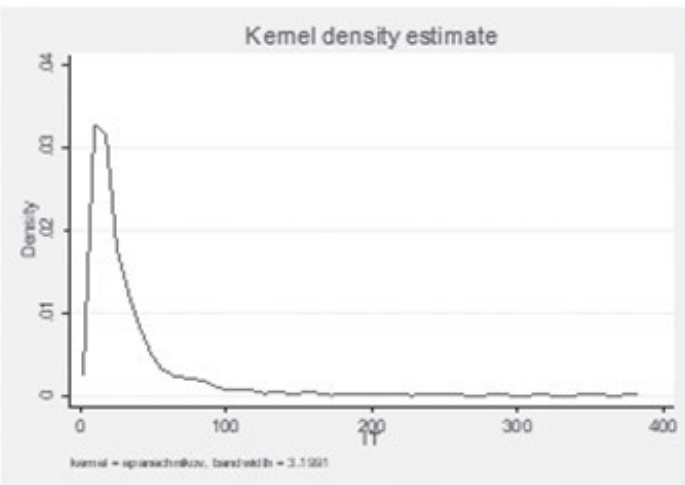

Italy 
regression coefficients. $\tau=0.5$ corresponds to the median regression.

\section{RESULTS}

In order to test possible structural differences between the four markets, in a first stage (pooled data analysis) and using robust OLS, joint regressions for the four samples are estimated (without color separation), followed by an application of the Chow test. Results from this test on 22 dataset combinations (combinations between one dataset and the three others; combinations between one dataset and the two others; and combinations between paired datasets - see Table B.1, Appendix B) allow us to conclude that the determinants of wine prices in the four markets are structurally different. Given the Kernel density of the dependent variable, quantile regressions were considered, estimated and tested. In a second stage (red and white wines analysis), after the application of the Chow test for structural differences between wine color (see Table B.2, Appendix B), a separated analysis for red and white wine was made to check whether the determinants of prices vary among both wines.

\subsection{Pooled data analysis}

With a general overview by markets, and for all price segments, the results from quantile regressions (Tables 3 and 4) and interquantile differences tests (Appendix C) show that the greatest divergences in price determinants occur between the $25^{\text {th }}$ and $50^{\text {th }}$ and $25^{\text {th }}$ and $75^{\text {th }}$ quantiles. The importance of alcohol and blend in price formation in all countries but France seem to be homogeneous in all ranges.

Results show that in the Australian retailer, closure type, age, medals and color are the positive price determinants. For the European samples, age, medals, Chardonnay variety and alcohol content are significant in Germany and France, while in the Italian sample the Sauvignon Blanc variety has a negative effect in the formation of higher price ranges. In the case of Chardonnay, it performs differently in the lower range of German retailer's prices (25-50 quantiles) and in Italy, but homogeneously in France. Additionally, national origin is only important for all price ranges in France, which contrasts with Italian results, where imported wines have higher prices. Thus, the only similarity for the four markets, and in all price segments, is the positive and significant effect of wine vintage for price determination, showing a different influence in all price ranges, except for high- er-priced wines in Australia (50-75 quantile). Moreover, for all but the upper price category (75-quantile) in Australia, the alcohol content is also a positive and significant driver of the wine price. A similar pattern was found for Australian, German and French shops, with the price being determined by medals in all segments. Alcohol content influences the price determination in all European shops, while in Australia it only influences the medium-low price range. In the German and Australian retailers, the wine origin appears to be important only for cheaper wines. Additionally, cork closure type has a positive effect on wine prices in French and Australian shops, in the medium-low price range (25-quantile and 50 -quantile) and in all segments, respectively. The other variables seem to influence wine prices with different magnitude and sign, across price quantiles and retailers.

Regarding grape variety, Chardonnay is a positive determinant in the case of the most expensive wines (50-quantile and 75-quantile) in Australia, for cheaper wines in Italy and in all segments in the German and French retailers. Regarding color effect (red wine), it is positive in all price segments in Australia and only for cheaper wines in Germany. On the contrary, it penalizes all price groups in Italy and the cheaper segment in France. Sauvignon Blanc variety has a positive influence on the definition of wine prices only in the German retailer, but only in the low price range. In France, Syrah variety has a positive effect on all price levels.

Results for closure types may suggest that, in Europe, perceptions that associate screw-capped bottles with low-quality wine may be declining, as the cork closure does not affect the Italian retailer price formation and a negative effect in the medium-high price segments in Germany. On the other hand, despite being phased out by the majority of Australian winemakers since 2000, the cork cap seems to be a positive determinant of wine prices in Australia in all price ranges. Also, Reserve or Grand Reserve status has a positive and homogeneous effect in the determination of wine prices in the low-price segment and for the most expensive wines in Australia, which contrasts with the other retailers under analysis. This seems to suggest that this quality signal may not be important in these markets, or other wine quality classifications may take place. The negative effect found for Blend coefficient suggests the importance of single-varietal wines in all retailers.

\subsection{Red and white wines analysis}

Appendix D includes the detailed results of the quantile regression by color for each country, being all the regressions globally and statistically significant, and 
Table 3. Quantile regression results for Australian and German shops.

\begin{tabular}{|c|c|c|c|c|c|c|c|c|}
\hline & \multicolumn{4}{|c|}{ Vintage Cellars - Australia } & \multicolumn{4}{|c|}{ Vinexus - Germany } \\
\hline & 25-quantile ${ }^{\mathrm{a}}$ & 50-quantile ${ }^{\mathrm{a}}$ & 75-quantile ${ }^{a}$ & $\mathrm{OLS}^{\mathrm{b}}$ & 25-quantile ${ }^{a}$ & 50-quantile ${ }^{\mathrm{a}}$ & 75-quantile ${ }^{\mathrm{a}}$ & $\mathrm{OLS}^{\mathrm{b}}$ \\
\hline Reserve & $\begin{array}{l}0.130^{* *} \\
(0.065)\end{array}$ & $\begin{array}{c}0.081 \\
(0.061)\end{array}$ & $\begin{array}{l}0.150^{*} \\
(0.084)\end{array}$ & $\begin{array}{c}0.085 \\
(0.053)\end{array}$ & $\begin{array}{l}-0.030 \\
(0.024)\end{array}$ & $\begin{array}{c}-0.106^{* * *} \\
(0.027)\end{array}$ & $\begin{array}{c}-0.150^{* * *} \\
(0.032)\end{array}$ & $\begin{array}{c}-0.103^{* * *} \\
(0.019)\end{array}$ \\
\hline Closure & $\begin{array}{c}0.353^{* * *} \\
(0.031)\end{array}$ & $\begin{array}{c}0.450^{* * *} \\
(0.032)\end{array}$ & $\begin{array}{c}0.466^{* * *} \\
(0.044)\end{array}$ & $\begin{array}{c}0.432^{* * *} \\
(0.024)\end{array}$ & $\begin{array}{c}-0.013 \\
(0.012)\end{array}$ & $\begin{array}{c}-0.040^{* * *} \\
(0.014)\end{array}$ & $\begin{array}{c}-0.039^{\star *} \\
(0.015)\end{array}$ & $\begin{array}{c}-0.042^{* * *} \\
(0.010)\end{array}$ \\
\hline Wine origin & $\begin{array}{l}0.047^{* *} \\
(0.019)\end{array}$ & $\begin{array}{c}-0.017 \\
(0.018)\end{array}$ & $\begin{array}{c}-0.037 \\
(0.024)\end{array}$ & $\begin{array}{l}-0.017 \\
(0.016)\end{array}$ & $\begin{array}{c}0.055^{\star * *} \\
(0.015)\end{array}$ & $\begin{array}{c}0.009 \\
(0.017)\end{array}$ & $\begin{array}{c}-0.004 \\
(0.018)\end{array}$ & $\begin{array}{l}0.028^{\star *} \\
(0.013)\end{array}$ \\
\hline Age & $\begin{array}{c}0.015^{\star * *} \\
(0.004)\end{array}$ & $\begin{array}{c}0.020^{* * *} \\
(0.004)\end{array}$ & $\begin{array}{c}0.026^{* * *} \\
(0.005)\end{array}$ & $\begin{array}{c}0.022^{* * *} \\
(0.004)\end{array}$ & $\begin{array}{c}0.059^{* * *} \\
(0.005)\end{array}$ & $\begin{array}{c}0.077^{\star * *} \\
(0.005)\end{array}$ & $\begin{array}{c}0.089^{* * *} \\
(0.004)\end{array}$ & $\begin{array}{c}0.067^{* * *} \\
(0.003)\end{array}$ \\
\hline Awards or medals & $\begin{array}{c}0.074^{* * *} \\
(0.021)\end{array}$ & $\begin{array}{c}0.164^{* * *} \\
(0.027)\end{array}$ & $\begin{array}{c}0.240^{\star * *} \\
(0.041)\end{array}$ & $\begin{array}{c}0.174^{* * *} \\
(0.023)\end{array}$ & $\begin{array}{c}0.092^{* * *} \\
(0.012)\end{array}$ & $\begin{array}{c}0.096^{* * *} \\
(0.013)\end{array}$ & $\begin{array}{c}0.097^{* * *} \\
(0.014)\end{array}$ & $\begin{array}{c}0.098^{* * *} \\
(0.009)\end{array}$ \\
\hline AlcCont & $\begin{array}{c}0.032^{\star * *} \\
(0.010)\end{array}$ & $\begin{array}{c}0.030^{* * *} \\
(0.011)\end{array}$ & $\begin{array}{c}0.009 \\
(0.012)\end{array}$ & $\begin{array}{c}0.027^{* * *} \\
(0.009)\end{array}$ & $\begin{array}{c}0.075^{* * *} \\
(0.008)\end{array}$ & $\begin{array}{c}0.065^{* * *} \\
(0.010)\end{array}$ & $\begin{array}{c}0.071^{* * *} \\
(0.009)\end{array}$ & $\begin{array}{c}0.081^{\star * *} \\
(0.007)\end{array}$ \\
\hline Blend & $\begin{array}{c}-0.080^{\star *} \\
(0.035)\end{array}$ & $\begin{array}{c}-0.081^{\star * *} \\
(0.028)\end{array}$ & $\begin{array}{c}-0.060 \\
(0.051)\end{array}$ & $\begin{array}{c}-0.042 \\
(0.032)\end{array}$ & $\begin{array}{c}-0.040^{* * *} \\
(0.019)\end{array}$ & $\begin{array}{l}-0.038^{\star} \\
(0.022)\end{array}$ & $\begin{array}{c}-0.024 \\
(0.028)\end{array}$ & $\begin{array}{c}-0.011 \\
(0.016)\end{array}$ \\
\hline $\begin{array}{l}\text { Cabernet } \\
\text { Sauvignon }\end{array}$ & $\begin{array}{l}-0.053^{*} \\
(0.029)\end{array}$ & $\begin{array}{c}-0.049^{* *} \\
(0.027)\end{array}$ & $\begin{array}{c}-0.017 \\
(0.041)\end{array}$ & $\begin{array}{c}0.001 \\
(0.024)\end{array}$ & $\begin{array}{c}-0.070^{* * *} \\
(0.019)\end{array}$ & $\begin{array}{c}-0.072^{* *} \\
(0.029)\end{array}$ & $\begin{array}{c}-0.084^{* * *} \\
(0.032)\end{array}$ & $\begin{array}{c}-0.069^{* * *} \\
(0.022)\end{array}$ \\
\hline Syrah & $\begin{array}{l}-0.005 \\
(0.023)\end{array}$ & $\begin{array}{c}-0.008 \\
(0.021)\end{array}$ & $\begin{array}{c}0.037 \\
(0.035)\end{array}$ & $\begin{array}{l}0.047^{\star *} \\
(0.021)\end{array}$ & $\begin{array}{l}-0.037 \\
(0.035)\end{array}$ & $\begin{array}{c}-0.023 \\
(0.037)\end{array}$ & $\begin{array}{c}-0.050 \\
(0.045)\end{array}$ & $\begin{array}{l}-0.024 \\
(0.028)\end{array}$ \\
\hline Sauvignon Blanc & $\begin{array}{c}-0.054^{* * *} \\
(0.019)\end{array}$ & $\begin{array}{c}-0.087^{* * *} \\
(0.022)\end{array}$ & $\begin{array}{c}-0.079^{* * *} \\
(0.028)\end{array}$ & $\begin{array}{c}-0.078^{* * *} \\
(0.018)\end{array}$ & $\begin{array}{c}0.102^{* * *} \\
(0.035)\end{array}$ & $\begin{array}{c}0.042 \\
(0.029)\end{array}$ & $\begin{array}{c}0.023 \\
(0.038)\end{array}$ & $\begin{array}{l}0.059^{* *} \\
(0.023)\end{array}$ \\
\hline Chardonnay & $\begin{array}{c}-0.004 \\
(0.025)\end{array}$ & $\begin{array}{c}0.073^{* * *} \\
(0.022)\end{array}$ & $\begin{array}{c}0.147^{* * *} \\
(0.033)\end{array}$ & $\begin{array}{c}0.082^{* * *} \\
(0.022)\end{array}$ & $\begin{array}{c}0.067^{\star * *} \\
(0.021)\end{array}$ & $\begin{array}{c}0.075^{\star * *} \\
(0.023)\end{array}$ & $\begin{array}{c}0.135^{\star * *} \\
(0.031)\end{array}$ & $\begin{array}{c}0.097^{* * *} \\
(0.018)\end{array}$ \\
\hline Color & $\begin{array}{c}0.072^{\star * *} \\
(0.027)\end{array}$ & $\begin{array}{c}0.122^{\star * *} \\
(0.021)\end{array}$ & $\begin{array}{c}0.206^{\star * \star} \\
(0.027)\end{array}$ & $\begin{array}{c}0.128^{\star * \star} \\
(0.021)\end{array}$ & $\begin{array}{c}0.060^{\star} \\
(0.035)\end{array}$ & $\begin{array}{c}0.034 \\
(0.029)\end{array}$ & $\begin{array}{c}0.043 \\
(0.038)\end{array}$ & $\begin{array}{l}0.058^{\star *} \\
(0.023)\end{array}$ \\
\hline Constant & $\begin{array}{c}0.491^{\star * *} \\
(0.138)\end{array}$ & $\begin{array}{c}0.644^{* * *} \\
(0.147)\end{array}$ & $\begin{array}{c}1.005^{\star * *} \\
(0.159)\end{array}$ & $\begin{array}{c}0.658^{* * *} \\
(0.130)\end{array}$ & $\begin{array}{c}-0.296^{* * * *} \\
(0.109)\end{array}$ & $\begin{array}{l}-0.042 \\
(0.129)\end{array}$ & $\begin{array}{l}-0.014 \\
(0.117)\end{array}$ & $\begin{array}{c}-0.237^{\star * *} \\
(0.086)\end{array}$ \\
\hline Observations & \multicolumn{4}{|c|}{2063} & \multicolumn{4}{|c|}{2664} \\
\hline R-squared & 0.14 & 0.23 & 0.32 & 0.44 & 0.17 & 0.20 & 0.24 & 0.35 \\
\hline
\end{tabular}

$*, * *, * * *$ denotes significance at $10 \%, 5 \%, 1 \%$.

aBootstrap standard errors in parentheses; Replications $=1000$.

${ }^{b}$ Robust standard errors in parentheses; OLS = ordinary least squares, included as reference.

Table 5 summarises these findings, showing the sign and statistical significance of the estimated coefficients.

In the Australian shop (Table D.1), the determinants of wine prices, excluding closure, perform very differently for red and white wines, and the reserve category became now insignificant. Cork closure, origin, age, medals, alcohol, and blend are important attributes for the red wines price setting. We may highlight the positive and homogeneous effect of alcohol content in all price segments, while blended wines receive a negative price premium in all price ranges and a red wine produced in Australia has a negative premium in the highest one. In the case of white wines, some predictors became irrelevant in price formation - reserve, origin, age, and blend - and the remaining, except Chardonnay, have a homogeneous effect in the different quantiles. The alcohol content is a significant predictor only for cheaper wines, and awards or medals do not influence the medium range.

In the German wine retailer (Table D.2), the price of red wines is negatively influenced by the reserve category, cork closure, blended varieties, and cabernet sauvignon. On the other hand, the national origin is a positive determinant for cheaper red wines, but a negative determinant for higher-priced white wines. The wine vintage, alcohol, and awards received have a positive influence, both in the red and white wine prices. In the case of the most expensive white wines, medals and awards do not influence pricing. Inversely to the reds, a blended white wine receives a positive price premium, particularly in higher segments, and the two white varieties under analysis have a homogeneous and positive effect on price setting.

In the French retailer (Table D.3), all wine characteristics are important for red and white wine's price for- 
Table 4. Quantile regression results for French and Italian shops.

\begin{tabular}{|c|c|c|c|c|c|c|c|c|}
\hline & \multicolumn{4}{|c|}{ Vinatis - France } & \multicolumn{4}{|c|}{ XtraWine - Italy } \\
\hline & 25-quantile ${ }^{\mathrm{a}}$ & 50-quantile ${ }^{a}$ & 75-quantile & OLS $^{b}$ & 25-quantile & 50-quantile ${ }^{a}$ & 75-quantile ${ }^{\mathrm{a}}$ & $\mathrm{OLS}^{\mathrm{b}}$ \\
\hline Reserve & $\begin{array}{c}-0.114^{\star * *} \\
(0.033)\end{array}$ & $\begin{array}{c}-0.137^{\star * *} \\
(0.032)\end{array}$ & $\begin{array}{c}-0.215^{\star * *} \\
(0.058)\end{array}$ & $\begin{array}{c}-0.186^{* \star *} \\
(0.036)\end{array}$ & $\begin{array}{c}0.011 \\
(0.017)\end{array}$ & $\begin{array}{c}0.006 \\
(0.025)\end{array}$ & $\begin{array}{l}-0.031 \\
(0.025)\end{array}$ & $\begin{array}{l}-0.005 \\
(0.017)\end{array}$ \\
\hline Closure & $\begin{array}{c}0.141^{* * *} \\
(0.028)\end{array}$ & $\begin{array}{c}0.156^{* * *} \\
(0.040)\end{array}$ & $\begin{array}{c}0.075 \\
(0.067)\end{array}$ & $\begin{array}{c}0.174^{* * *} \\
(0.031)\end{array}$ & $\begin{array}{c}0.017 \\
(0.046)\end{array}$ & $\begin{array}{c}0.056 \\
(0.068)\end{array}$ & $\begin{array}{c}0.058 \\
(0.070)\end{array}$ & $\begin{array}{c}0.043 \\
(0.039)\end{array}$ \\
\hline Wine origin & $\begin{array}{l}0.042^{\star *} \\
(0.019)\end{array}$ & $\begin{array}{c}0.082^{* * *} \\
(0.027)\end{array}$ & $\begin{array}{l}0.090^{\star *} \\
(0.043)\end{array}$ & $\begin{array}{c}0.036 \\
(0.027)\end{array}$ & $\begin{array}{c}-0.177^{* * *} \\
(0.015)\end{array}$ & $\begin{array}{c}-0.259^{* * *} \\
(0.019)\end{array}$ & $\begin{array}{c}-0.344^{* * *} \\
(0.030)\end{array}$ & $\begin{array}{c}-0.273^{* * *} \\
(0.015)\end{array}$ \\
\hline Age & $\begin{array}{c}0.078^{\star * *} \\
(0.007)\end{array}$ & $\begin{array}{c}0.104^{* * *} \\
(0.006)\end{array}$ & $\begin{array}{c}0.115^{\star * *} \\
(0.007)\end{array}$ & $\begin{array}{c}0.092^{* * *} \\
(0.004)\end{array}$ & $\begin{array}{c}0.059^{* * *} \\
(0.003)\end{array}$ & $\begin{array}{c}0.073^{* * *} \\
(0.004)\end{array}$ & $\begin{array}{c}0.084^{* * *} \\
(0.006)\end{array}$ & $\begin{array}{c}0.061^{* * *} \\
(0.004)\end{array}$ \\
\hline Awards or medals & $\begin{array}{c}0.058^{* * *} \\
(0.015)\end{array}$ & $\begin{array}{c}0.076^{* * *} \\
(0.018)\end{array}$ & $\begin{array}{c}0.106^{* * *} \\
(0.025)\end{array}$ & $\begin{array}{c}0.104^{* * *} \\
(0.014)\end{array}$ & $\begin{array}{c}0.052 \\
(0.046)\end{array}$ & $\begin{array}{c}0.029 \\
(0.068)\end{array}$ & $\begin{array}{c}0.051 \\
(0.070)\end{array}$ & $\begin{array}{l}0.073^{\star} \\
(0.039)\end{array}$ \\
\hline AlcCont & $\begin{array}{c}0.070^{* * *} \\
(0.009)\end{array}$ & $\begin{array}{c}0.095^{\star * *} \\
(0.012)\end{array}$ & $\begin{array}{c}0.104^{* * *} \\
(0.015)\end{array}$ & $\begin{array}{c}0.081^{* * *} \\
(0.009)\end{array}$ & $\begin{array}{c}0.089^{* * *} \\
(0.007)\end{array}$ & $\begin{array}{c}0.093^{* * *} \\
(0.008)\end{array}$ & $\begin{array}{c}0.102^{* * *} \\
(0.011)\end{array}$ & $\begin{array}{c}0.108^{* * *} \\
(0.006)\end{array}$ \\
\hline Blend & $\begin{array}{c}-0.096^{* * *} \\
(0.016)\end{array}$ & $\begin{array}{c}-0.134^{\star * *} \\
(0.019)\end{array}$ & $\begin{array}{c}-0.158^{* * *} \\
(0.027)\end{array}$ & $\begin{array}{c}-0.122^{\star * \star} \\
(0.016)\end{array}$ & $\begin{array}{c}-0.073^{* * *} \\
(0.010)\end{array}$ & $\begin{array}{c}-0.076^{* * *} \\
(0.012)\end{array}$ & $\begin{array}{c}-0.085^{\star * *} \\
(0.015)\end{array}$ & $\begin{array}{c}-0.104^{\star * *} \\
(0.011)\end{array}$ \\
\hline $\begin{array}{l}\text { Cabernet } \\
\text { Sauvignon }\end{array}$ & $\begin{array}{c}-0.141^{\star} \\
(0.076)\end{array}$ & $\begin{array}{c}-0.266^{\star} \\
(0.147)\end{array}$ & $\begin{array}{c}-0.092 \\
(0.258)\end{array}$ & $\begin{array}{l}-0.165 \\
(0.011)\end{array}$ & $\begin{array}{l}-0.113^{\star} \\
(0.061)\end{array}$ & $\begin{array}{l}-0.067 \\
(0.065)\end{array}$ & $\begin{array}{l}-0.024 \\
(0.071)\end{array}$ & $\begin{array}{l}-0.049 \\
(0.048)\end{array}$ \\
\hline Syrah & $\begin{array}{c}0.141^{* * *} \\
(0.025)\end{array}$ & $\begin{array}{l}0.084^{* *} \\
(0.036)\end{array}$ & $\begin{array}{c}0.079^{*} \\
(0.046)\end{array}$ & $\begin{array}{c}0.077^{* * *} \\
(0.027)\end{array}$ & $\begin{array}{l}-0.036 \\
(0.038)\end{array}$ & $\begin{array}{l}-0.007 \\
(0.058)\end{array}$ & $\begin{array}{c}-0.042 \\
(0.125)\end{array}$ & $\begin{array}{l}-0.008 \\
(0.048)\end{array}$ \\
\hline Sauvignon Blanc & $\begin{array}{l}-0.005 \\
(0.042)\end{array}$ & $\begin{array}{c}-0.038 \\
(0.037)\end{array}$ & $\begin{array}{c}-0.161^{\star * *} \\
(0.039)\end{array}$ & $\begin{array}{c}-0.076^{\star * *} \\
(0.027)\end{array}$ & $\begin{array}{c}0.005 \\
(0.021)\end{array}$ & $\begin{array}{l}-0.007 \\
(0.022)\end{array}$ & $\begin{array}{c}-0.102^{* * *} \\
(0.019)\end{array}$ & $\begin{array}{c}-0.074^{* * *} \\
(0.021)\end{array}$ \\
\hline Chardonnay & $\begin{array}{c}0.108^{* * *} \\
(0.029)\end{array}$ & $\begin{array}{c}0.112^{* * *} \\
(0.030)\end{array}$ & $\begin{array}{c}0.115^{\star * *} \\
(0.044)\end{array}$ & $\begin{array}{c}0.114^{* * *} \\
(0.025)\end{array}$ & $\begin{array}{c}0.093^{* * *} \\
(0.021)\end{array}$ & $\begin{array}{l}0.039^{*} \\
(0.023)\end{array}$ & $\begin{array}{l}-0.033 \\
(0.035)\end{array}$ & $\begin{array}{c}0.006 \\
(0.022)\end{array}$ \\
\hline Color & $\begin{array}{c}-0.047^{\star *} \\
(0.019)\end{array}$ & $\begin{array}{l}-0.029 \\
(0.020)\end{array}$ & $\begin{array}{c}-0.021 \\
(0.028)\end{array}$ & $\begin{array}{l}-0.007 \\
(0.017)\end{array}$ & $\begin{array}{c}-0.063^{* * *} \\
(0.010)\end{array}$ & $\begin{array}{c}-0.054^{* * *} \\
(0.012)\end{array}$ & $\begin{array}{c}-0.074^{* * *} \\
(0.016)\end{array}$ & $\begin{array}{c}-0.059^{* * *} \\
(0.011)\end{array}$ \\
\hline Constant & $\begin{array}{l}-0.219^{*} \\
(0.117)\end{array}$ & $\begin{array}{c}-0.526^{* * *} \\
(0.150)\end{array}$ & $\begin{array}{c}-0.435^{\star *} \\
(0.197)\end{array}$ & $\begin{array}{c}-0.279^{* *} \\
(0.121)\end{array}$ & $\begin{array}{l}-0.149^{*} \\
(0.089)\end{array}$ & $\begin{array}{c}-0.081 \\
(0.091)\end{array}$ & $\begin{array}{c}-0.012 \\
(0.131)\end{array}$ & $\begin{array}{c}-0.204^{* * *} \\
(0.078)\end{array}$ \\
\hline Observations & \multicolumn{4}{|c|}{2094} & \multicolumn{4}{|c|}{2803} \\
\hline R-squared & 0.20 & 0.23 & 0.24 & 0.37 & 0.26 & 0.29 & 0.29 & 0.43 \\
\hline
\end{tabular}

$*, * *, * *$ denotes significance at $10 \%, 5 \%, 1 \%$.

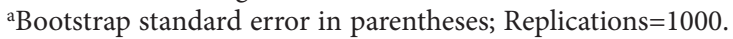

${ }^{b}$ Robust standard errors in parentheses; OLS = ordinary least squares, included as reference.

mation, except wine origin, which became insignificant for white wines pricing. The effect of Sauvignon Blanc variety is positive for cheaper wines, while negative in the case of the most expensive segments. The majority of red wine price determinants perform differently across the different quantiles, except closure type, wine origin and Cabernet Sauvignon variety. According to the interquartile differences tests' results, in the case of white wines, the determinants of price have a more homogeneous effect in the price formation.

Finally, for the Italian retailer (Table D.4), both wine origin and vintage have a similar effect in both red and white wine prices but perform differently across wines quantiles. Italian wines receive a negative price premium, with a higher magnitude for more expensive wines, while vintage positively affects prices in all segments. Alcohol content has a homogeneous and positive effect in all quantiles, while a blended wine receives a negative price premium. The analysis by wine color, revealed that closure type became statistically significant while having a cork cap negatively affects the price of cheaper red wines but having a positive impact on the price of white wines. Syrah variety also became a determinant of price, having a negative influence on the medium-lower range prices. Sauvignon Blanc variety appears to particularly have a negative impact in the prices setting in the most expensive segments of white wines.

Broadly, the results show that the implicit prices of wine attributes such as wine origin and blend category differ for red and white wines, in line with [13], in all retailers except for the Italian. Additionally, closure type also performs differently in Germany and Italy, adding to this last one, the different effects of awards or medals. In Australia, the ageing potential for red 
Table 5. Summary of quantile regression results by color, for each country.

\begin{tabular}{|c|c|c|c|c|c|c|c|c|c|c|c|c|}
\hline \multirow{4}{*}{ Variable } & \multicolumn{12}{|l|}{ Quantile } \\
\hline & \multicolumn{6}{|c|}{ Australia } & \multicolumn{6}{|c|}{ Germany } \\
\hline & \multicolumn{3}{|c|}{ Red } & \multicolumn{3}{|c|}{ White } & \multicolumn{3}{|c|}{ Red } & \multicolumn{3}{|c|}{ White } \\
\hline & 25 & 50 & 75 & 25 & 50 & 75 & 25 & 50 & 75 & 25 & 50 & 75 \\
\hline Reserve & n.s. & n.s. & n.s. & n.s. & n.s. & n.s. & n.s. & $(-)^{* * *}$ & $(-)^{* * *}$ & $(-)^{* * *}$ & $(-)^{* *}$ & $(-)^{* * *}$ \\
\hline Closure & $(+)^{* * *}$ & $(+)^{* * *}$ & $(+)^{* * *}$ & $(+)^{* * *}$ & $(+)^{* * *}$ & $(+)^{* * *}$ & $(-)^{*}$ & $(-)^{* * *}$ & $(-)^{* * *}$ & n.s. & n.s. & n.s. \\
\hline Wine origin & $(+)^{* *}$ & n.s. & $(-)^{\star *}$ & n.s. & n.s. & n.s. & $(+)^{* * *}$ & n.s. & n.s. & n.s. & n.s. & $(-)^{\star *}$ \\
\hline Age & $(+)^{* *}$ & $(+)^{* * *}$ & $(+)^{* * *}$ & n.s. & n.s. & n.s. & $(+)^{* * *}$ & $(+)^{* * *}$ & $(+)^{* * *}$ & $(+)^{* * *}$ & $(+)^{* * *}$ & $(+)^{* * *}$ \\
\hline Awards or medals & $(+)^{* * *}$ & $(+)^{* * *}$ & $(+)^{* * *}$ & $(+)^{* *}$ & n.s. & $(+)^{*}$ & $(+)^{* * *}$ & $(+)^{* * *}$ & $(+)^{* * *}$ & $(+)^{* *}$ & $(+)^{* * *}$ & n.s. \\
\hline AlcCont & $(+)^{* * *}$ & $(+)^{* * *}$ & $(+)^{* *}$ & $(+)^{* * *}$ & n.s. & n.s. & $(+)^{* * *}$ & $(+)^{* * *}$ & $(+)^{* * *}$ & $(+)^{* * *}$ & $(+)^{* * *}$ & $(+)^{* * *}$ \\
\hline Blend & $(-)^{* * *}$ & $(-)^{* * *}$ & $(-)^{*}$ & n.s. & n.s. & n.s. & $(-)^{* *}$ & $(-)^{*}$ & $(-)^{*}$ & n.s. & $(+)^{*}$ & $(+)^{* *}$ \\
\hline Cabernet Sauvignon & n.s. & n.s. & n.s. & & & & $(-)^{* * *}$ & $(-)^{* * *}$ & $(-)^{* * *}$ & & & \\
\hline Syrah & n.s. & n.s. & n.s. & & & & n.s. & n.s. & n.s. & & & \\
\hline Sauvignon Blanc & & & & $(-)^{* * *}$ & $(-)^{* * *}$ & $(-)^{\star *}$ & & & & $(+)^{* * *}$ & $(+)^{* * *}$ & $(+)^{* * *}$ \\
\hline \multirow[t]{4}{*}{ Chardonnay } & & & & n.s. & $(+)^{* * *}$ & $(+)^{* * *}$ & & & & $(+)^{* * *}$ & $(+)^{* * *}$ & $(+)^{* * *}$ \\
\hline & \multicolumn{6}{|c|}{ France } & \multicolumn{6}{|c|}{ Italy } \\
\hline & \multicolumn{3}{|c|}{ Red } & \multicolumn{3}{|c|}{ White } & \multicolumn{3}{|c|}{ Red } & \multicolumn{3}{|c|}{ White } \\
\hline & 25 & 50 & 75 & 25 & 50 & 75 & 25 & 50 & 75 & 25 & 50 & 75 \\
\hline Reserve & $(-)^{\star \star}$ & $(-)^{\star *}$ & $(-)^{* * *}$ & $(-)^{\star * *}$ & $(-)^{\star *}$ & n.s. & n.s. & n.s. & n.s. & n.s. & n.s. & n.s. \\
\hline Closure & $(+)^{* * *}$ & $(+)^{* *}$ & $(+)^{* *}$ & $(+)^{* * *}$ & $(+)^{* * *}$ & n.s. & $(-)^{\star *}$ & n.s. & n.s. & $(+)^{\star *}$ & $(+)^{* * *}$ & $(+)^{* *}$ \\
\hline Wine origin & $(+)^{* *}$ & $(+)^{* *}$ & n.s. & n.s. & n.s. & n.s. & $(-)^{* * *}$ & $(-)^{* * *}$ & $(-)^{* * *}$ & $(-)^{* * *}$ & $(-)^{* * *}$ & $(-)^{* * *}$ \\
\hline Age & $(+)^{* * *}$ & $(+)^{* * *}$ & $(+)^{* * *}$ & $(+)^{* * *}$ & $(+)^{* * *}$ & $(+)^{* * *}$ & $(+)^{* * *}$ & $(+)^{* * *}$ & $(+)^{* * *}$ & $(+)^{* * *}$ & $(+)^{* * *}$ & $(+)^{* * *}$ \\
\hline Awards or medals & $(+)^{* * *}$ & $(+)^{* * *}$ & $(+)^{* * *}$ & $(+)^{* * *}$ & $(+)^{* * *}$ & $(+)^{*}$ & $(+)^{* * *}$ & $(+)^{* * *}$ & $(+) *$ & n.s. & n.s. & n.s. \\
\hline AlcCont & $(+)^{* * *}$ & $(+)^{* * *}$ & $(+)^{* * *}$ & $(+)^{* * *}$ & $(+)^{* * *}$ & $(+)^{* * *}$ & $(+)^{* * *}$ & $(+)^{* * *}$ & $(+)^{* * *}$ & $(+)^{* * *}$ & $(+)^{* * *}$ & $(+)^{* * *}$ \\
\hline Blend & $(-)^{* * *}$ & $(-)^{* * *}$ & $(-)^{* * *}$ & $(-)^{*}$ & $(-)^{*}$ & n.s. & $(-)^{* * *}$ & $(-)^{* * *}$ & $(-)^{* * *}$ & $(-)^{* * *}$ & $(-)^{* * *}$ & $(-)^{* * *}$ \\
\hline Cabernet Sauvignon & n.s. & $(-)^{* *}$ & n.s. & & & & n.s. & n.s. & n.s. & & & \\
\hline Syrah & $(+)^{* * *}$ & $(+)^{*}$ & n.s. & & & & $(-)^{*}$ & $(-)^{*}$ & n.s. & & & \\
\hline Sauvignon Blanc & & & & $(+)^{*}$ & n.s. & $(-)^{* *}$ & & & & n.s. & n.s. & $(-)^{* * *}$ \\
\hline Chardonnay & & & & $(+)^{* * *}$ & $(+)^{* * *}$ & $(+)^{* * *}$ & & & & $(+)^{* * *}$ & n.s. & n.s. \\
\hline
\end{tabular}

${ }^{*}, * *, * *$ denotes significance at $10 \%, 5 \%, 1 \%$; n.s. stands for non-significant effects

wines is very distinct from that of white wines, corroborating [17].

\section{CONCLUSIONS}

This investigation aimed to understand whether exists a homogeneous international standard on the attributes that influence wine prices sold in a similar distribution channel. To achieve this goal, we estimated hedonic price functions on four different wine markets, using data from specialist retailers.

The results led us to conclude that, despite the standardization of the world wine market, locally and by market and market segment, there is still differentia- tion in the consumer appraisal of wine price attributes and therefore in the price determinants. Data collected show that, on average, the demand structure in Australia, Germany, France and Italy is very similar in terms of alcohol content, vintage and Reserve/Grand Reserve category. Domestic wine is dominant in producing countries. Moreover, while Old World (Italian and French) privilege blend, cork cap and awarded wine, New World stress the varietal component of wine and screw tops. The price structure is heterogeneous, both within the country and between countries. French wine presents the highest average price while German wine shows the lowest one; additionally, the wine share in the lowest and highest price segments is also distinct within each market. 
The findings show that the price determinants are structurally different (i) among countries, (ii) for price segments in each country, and (iii) whether the wine is red or white, disallowing to extrapolate results from one market to other markets, and from red to white wines. However, both between the four markets and across market segments there are similarities and differences in the effects of wine attributes on prices.

Regarding similarities, the age or vintage is a positive driver of the price for all ranges in all countries, except for Australia when comparing red to white wines. The alcohol content plays an identical positive effect (for total wine or pooled data, and by color), except for the highest-priced wine in Australia, which also applies in the case of white wines. For total wine, medals or awards are positive wine determinants in all markets, except in the Italian market. However, when segmenting by color, it has distinct effects. In the case of Australia, medals or awards positively contribute to increasing the price of the cheapest and the most expensive white wines. Oppositely, in Italy, this attribute is only relevant for red wines, and in Germany, the price of the most expensive white wines is not determined by an award or medal. Being a blended wine decreases the price of wine (total, red, and white) and Cabernet Sauvignon presents consistently a negative influence, particularly on the medium-low price range. When compared to other varieties, Chardonnay is a positive determinant, excluding the lowest price range in Australia and the highest in Italia, signing that it is one of the most recognized varieties in the world. Indeed, this is the most popular white variety in Australia, with an increasing effect and especially relevant in the medium-higher priced wines. Additionally, in this country, for the definition of white wine' prices in all segments, it is also important to have a cork closure.

In summary, despite some similarities, we found that the wine price determinants are very specific of each market, and also depending on the wine color. This demonstrates that wine is a complex and heterogenous product, and that there is not a homogeneous international standard.

In fact, in Australia the prices of wine (total) and the red one are positively influenced by a cork closure, vintage, awards or medals received, and alcohol level, and blended wines receive a negative price premium, as happens with national red wines in the highest segment of prices.

In Germany, the price of total wine, and also by color, is positively influenced by age, awards, and alcohol, being its effects increasing with price segments. However, in the case of white blended wines they receive a price premium in higher segments (contrasting with other countries). The white varieties positively influence all price ranges, and for an increase in price segments, Sauvignon Blanc has a decreasing effect, while Chardonnay registers an increasing contribution.

In France, for total wine and the red, cork cap, vintage, awards, and alcohol level have a positive effect in the majority of price ranges. French wines and Syrah variety are important predictors of the price for cheaper/ medium red segments. In the case of white wines, and as it happens with the reds, age, awards, and alcohol level are determinants of wine prices, with Chardonnay playing an important role similar to Germany. The cork closure is only relevant for cheaper wines.

In Italy, age and alcohol are the most important attributes for higher prices of wine (total) and also for red and white wines. Adding to what was stated above regarding awards/medals, these only produce a positive effect on the price of red wine. The cork closure in whites has an increasing impact as price segments increase, which registers an opposite effect for cheaper red wines, and no influence in higher segments. Contrary to the other retailers, Chardonnay variety is only important for cheaper wines.

Our results lead to the robust conclusion that there is not a single world wine and even a single country market but different wine markets, which is also true for red and white wines, with the significance or sign of attributes in wine price determination changing among countries and across price market segments. Thus, generalizing results based on country data and neglecting the effects of market segmentation on wine price determinants may lead to erroneous conclusions and managerial decisions that should be avoided.

The findings of this study recommend wineries to define marketing strategies and to supply wines according to the characteristics of the target market and to achieve a better match between supply and demand, to enhance their market shares, not only for different price segments but also different wine styles.

This work is not free of drawbacks, since the data sources from specialized wine retailers tend to cover only a small market share and/or market shares, unlike those of supermarkets/large distributors. Additionally, specialist retailers are off-trade channels who purchase wine through an agent or a wholesaler, leading to a double mark-up reflected in higher consumer prices, when compared to supermarkets, and the determinants of wine prices tend to be different when comparing specialist shops with other channels $[18,45]$. Future research should include other important determinants, such as the specific wine varieties (for white and red wines) for 
each country, and to address the effect of appellations and terroir on prices, which we believe may have a significant effect on price.

\section{ACKNOWLEDGMENTS}

This work is supported by the project VINCI Wine, Innovation and International Competitiveness, under the operation number SOE3/P2/F0917, FEDER Interreg SUDOE, and national funds, through the FCT - Portuguese Foundation for Science and Technology under the project UIDB/SOC/04011/2020. The authors thank to anonymous referees and also to Eduarda Correia for her support in data collection. The usual disclaimer applies.

\section{REFERENCES}

[1] A. Corsi, The Italian Wine Industry, in: A. Ugaglia, J-M. Cardebat, A. Corsi (Eds), The Palgrave Handbook of Wine Industry Economics. Palgrave Macmillan, Cham, 2019

[2] Amédée-Manesme, C. O., Faye, B., Le Fur, E., Heterogeneity and fine wine prices: application of the quantile regression approach, Appl Econ. (2019). https://doi.org/10.1080/00036846.2019.1696937

[3] Ashenfelter, O., Ashmore, D., Lalonde, R., Bordeaux wine vintage quality and the weather, Chance. 8(4) (1995) 7-14. https://doi.org/10.1080/0 9332480.1995.10542468

[4] Ashenfelter, O., Predicting the Quality and Prices of Bordeaux Wine, The Economic Journal. 118 (529) (2008) 174-184. https://doi.org/10.1111/ j.1468-0297.2008.02148.x

[5] Ashenfelter, O., Predicting the Quality and Prices of Bordeaux Wine. J. Wine Econ, 5 (1) (2010) 40-52. https://doi.org/10.1017/S193143610000136X

[6] Ashenfelter, O., Jones, G., The Demand for Expert Opinion: Bordeaux Wine, J. Wine Econ. 8(3) (2013) 285-293. https://doi.org/10.1017/jwe.2013.22

[7] Ashenfelter, O., Storchman, K., Climate Change and Wine: a review of the economic implications, J. Wine Econ. 11(1) (2016) 105-138. https://doi. org/10.1017/jwe.2016.5

[8] Ashton, R. H., Is there consensus among wine quality ratings of prominent critics? An empirical analysis of red Bordeaux, J. Wine Econ. 8(2) (2013) 225-234. https://doi.org/10.1017/jwe.2013.18

[9] Asgari, A., Reed, M., Price determinants of California wines in the U. S. market: Does the type mat- ter? Agricultural and Applied Economics Association (AAEA). Annual Meeting, Boston, MA, 2016.

[10] Benfratello, L., Piacenza, M., Sachetto, S., Taste or Reputation: what drives market prices in the wine industry? Estimation of a hedonic model for Italian premium wine, Appl Econ, 41(17) (2009) 21972209. https://doi.org/10.1080/00036840701222439

[11] Caldas, J., Rebelo, J., Portuguese wine ratings: An old product a new assessment, Wine Econ Policy. 2 (2013) 102-110. https://doi.org/10.1016/j. wep.2013.11.004

[12] Caracciolo, F., D'Amico, M., Di Vita, G., Pomarici, E., Dal Bianco, A., Cembalo, L., Private vs. collective reputation, Int. Food Agribusiness Manag. Rev. 19(3) (2016) 191-209. DOI:10.22004/ ag.econ. 244704

[13] Carew, R., Florkowski, W.J, Meng, T., Segmenting wine markets with diverse price functions: Evidence from California red and white wines sold in British Columbia, Wine Econ. Policy 6 (2017) 48-59. http://dx.doi.org/10.1016/j.wep.2017.05.002

[14] Castriota, St., Delmastro, M. 2008. Individual and Collective Reputation: Lessons from the Wine. Available at SSRN: https://ssrn.com/ abstract $=1349992$ or http://dx.doi.org/10.2139/ ssrn.1349992

[15] Combris, P., Lecocq, S., Visser, M., Estimation of a hedonic price equation for Bordeaux wine: Does quality matter? The Economic Journal. 107 (1997) 390-402.

[16] Combris, P., Lecocq, S., Visser, M., Estimation of a hedonic price equation for Burgundy wine, Appl Econ. 32 (2000) 961-967. https://doi. org/10.1080/000368400322011

[17] Costanigro, M., McCluskey, J. J., Mittlehammer, R. C., Segmenting the Wine Market Based on Price: Hedonic Regression when Different Prices mean Different Products, J. Agric. Econ. 58 (3) (2007) 454-466. https://doi.org/10.1111/j.14779552.2007.00118.x

[18] Di Vita, G., Caracciolo, F., Cembalo, L., Pomarici, E., Pomarici, E., D'Amico, M., Drinking wine at home: Hedonic analysis of Sicilian wines using quantile regression, Am. J. Appl. Sci. 12(10) (2015) 679-688. DOI:10.3844/ajassp.2015.679.688

[19] Dressler, M., The German Wine Market: A Comprehensive Strategic and Economic Analysis, Beverages. 4 (92) (2018) 11-28. https://doi.org/10.3390/ beverages 4040092

[20] Dubois, P., Nauges, C., Identifying the effect of unobserved quality and expert reviews in the pricing of experience goods: Empirical applica- 
tion on Bordeaux wine, Int. J. Ind. Organ. 28(3) (2010) 205-212. https://doi.org/10.1016/j.ijindorg.2009.08.003

[21] Faye, B., Le Fur, E., On the constancy of hedonic wine prices coefficients over time, J. Wine Econ. 14(2) (2019) 182-207. https://doi.org/10.1017/ jwe.2019.24

[22] Frick, B., Simmons, R., The impact of individual and collective reputation on wine prices: empirical evidence from the Mosel valley, J. Bus. Econ. 83(2) (2013) 101-119. https://doi.org/10.1007/s11573013-0652-x

[23] Gergaud, O., Livat, F., Warzynski, F. 2012. Collective reputation effects: an empirical appraisal. SSRN Electronic Journal. DOI:10.2139/ ssrn. 1708464.

[24] Ginsburgh, V., Monzak, M., Monzak, A., Red Wines of Médoc: What is Wine Tasting Worth, J. Wine Econ. 8(2) (2013) 159-188. https://doi. org/10.1017/jwe.2013.17

[25] Hadj Ali, H., Lecocq, S., Visser, M., The impact of gurus: Parker grades and en primeur wine prices, J. Wine Econ. 5(1) (2010) 22-39. https://doi. org/10.1017/S1931436100001358

[26] Haeger, J. W., Storchmann, K., Prices of American Pinot Noir wines: climate, craftsmanship, critics, Agric Econ. 35(1) (2006) 67-78. https://doi. org/10.1111/j.1574-0862.2006.00140.x

[27] Hinkle, W. Wiersma, S.G. Jurs, Applied Statistics for the Behavioral Sciences, fifth ed., Houghton Mifflin, Boston, 2003.

[28] Jones, G., Storchmann, K., Wine market prices and investment under uncertainty: an econometric model of Bordeaux Crus Classés, Agric Econ. 26(2) (2001) 115-133. https://doi.org/10.1016/ S0169-5150(00)00102-X

[29] K. Anderson, The Australian Wine Industry, in: A. Ugaglia, J-M. Cardebat, A. Corsi (Eds), The Palgrave Handbook of Wine Industry Economics. Palgrave Macmillan, Cham, 2019

[30] Koenker, R., Basset, G., Regression quantiles, Econometrica. 46(1) (1978) 33-50. DOI:10.2307/1913643

[31] Landon, S., Smith, C.E., The Use of Quality and Reputation Indicators by Consumers: The case of Bordeaux Wine, J. Consum. Policy. 20(3) (1997) 289-323. https://doi.org/10.1023/A:1006830218392

[32] Landon, S., Smith, C.E., Quality Expectations, Reputation and Price, South. Econ. J. 64(3) (1998) 628647. https://www.jstor.org/stable/1060783

[33] Lecocq, S., Visser, M., What determines wine prices: objective vs. sensory characteristics, J. Wine
Econ. 1(1) (2006) 42-56. https://doi.org/10.1017/ S1931436100000080

[34] Levaggi, R., Brentari, E., The Hedonic Price for Italian Red Wine: Do Chemical and Sensory Characteristics Matter? Agribusiness. 30(4) (2014) 385397. https://doi.org/10.1002/agr.21377

[35] Lima, T., Price and quality in the California wine industry: an empirical investigation, J. Wine Econ. 1(2) (2006) 176-19. DOI: 10.1017/S1931436100000201

[36] Ling, B. H., Lockshin, L., Components of wine prices for Australian wine: how winery reputation, wine quality, region, vintage and wine size contribute to the price of varietal wines, Australas Mark. J. 11(3) (2003) 19-32, https://doi.org/10.1016/S14413582(03)70132-3

[37] Oczkowski, E., A hedonic price function for Australian premium wine, Australian J. Agric. Econ. 38 (1994) 93-110. https://doi. org/10.1111/j.1467-8489.1994.tb00721.x

[38] Oczkowski, E., Hedonic Wine Price Functions and Measurement Error, Econ Rec. 77 (239) (2001) 374-382. https://doi.org/10.1111/1475-4932.00030

[39] Oczkowski, E. and Doucouliagos, H., Wine Prices and Quality Ratings. A Meta-Regression Analysis, American J. Agric. Econ. 97(1) (2014) 103-121. https://doi.org/10.1093/ajae/aau057

[40] Oczkowski, E., Hedonic price functions with different prices, Aust J Agric Resour Econ. 60(2) (2015) 196-211. https://doi.org/10.1111/1467-8489.12112

[41] Oczkowski, E., Identifying the effects of objective and subjective quality on wine prices, J. Wine Econ. 11(2) (2016) 249-260. https://doi. org/10.1017/jwe.2016.1

[42] Outreville, J-F., Le Fur, E., Hedonic Price Functions and Wine Price Determinants: A Review of Empirical Research, J. Agric. Food Ind. Organ. (2020). DOI: https://doi.org/10.1515/jafio-2019-0028.

[43] Pomarici, E., Recent trends in the international wine market and arising research questions, Wine Econ Policy. 5 (2016) 1-3. DOI: 10.1016/j. wep.2016.06.001

[44] Rabobank, 2019. Wine Quarterly Q1 2019: Online Wine Is Growing in Europe (available at https:// research.rabobank.com/far/en/sectors/beverages/ wine-quarterly-q1-2019.html)

[45] Rebelo, J., Lourenço-Gomes, L., Gonçalves, T., Caldas, J., A hedonic price analysis for the Portuguese wine market: Does the distribution channel matter? Journal of Appl Econ. 22(1) 2019 40-59. doi: 10.1080/15140326.2018.1550596

[46] Roma, P., Di Martino, G., Perrone, G., What to show on the wine labels: a hedonic analysis of price 
drivers of Sicilian wines, Appl Econ. 45(19) (2013) 2765-2778. DOI: 10.1080/00036846.2012.678983

[47] Rosen, S., Hedonic prices and implicit markets: Product differentiation in pure competition, J Polit Econ. 82(1) (1974) 34-55. DOI: https://www.jstor. org/stable/1830899

[48] San Martin, G., Brummer, B., Troncoso, J., Determinants of Argentinean wine prices in the U.S. market, J. Wine Econ. 3(1) (2008) 72-84. DOI: https://doi.org/10.1017/S1931436100000560

[49] Schamel, G., A hedonic pricing model for German wine, German J. Agric. Econ. 52 (2003) 247-254. DOI: 10.22004/ag.econ.97975

[50] Schamel, G., Geography versus Brands in a Global Wine Market, Agribusiness. 22(3), (2006) 363-374. https://doi.org/10.1002/agr.20091

[51] Schamel, G., Dynamic analysis of brand and regional reputation, J. Wine Econ. 4(1) (2009) 62-80. https://doi.org/10.1017/S1931436100000687

[52] Thrane, C., In Defence of the Price Hedonic Model in Wine Research, J. Wine Res. 15(2) (2004) 123134.

[53] Ugaglia, J-M. Cardebat, L. Jiao, The French Wine Industry, in: A. Ugaglia, J-M. Cardebat, A. Corsi (Eds), The Palgrave Handbook of Wine Industry Economics. Palgrave Macmillan, Cham, 2019

[54] Wood, D., Anderson, K., What determines the future value of an icon wine? New evidence from Australia, J. Wine Econ. 1(2) (2006) 141-161. https://doi.org/10.1017/S1931436100000171 


\section{APPENDIX A}

Table A1. Phi correlation between binary variables for each country.

\begin{tabular}{|c|c|c|c|c|c|c|c|c|c|c|}
\hline & Reserve & Cap & Origin & Medals & Blend & CabSauv & Syrah & SauvBlanc & Chardonnay & Color \\
\hline \multicolumn{11}{|l|}{ France } \\
\hline Reserve & 1.0000 & & & & & & & & & \\
\hline Cap & -0.0119 & 1.0000 & & & & & & & & \\
\hline Origin & $-0.1305^{\star \star \star}$ & $0.2301^{\star \star \star}$ & 1.0000 & & & & & & & \\
\hline Medals & 0.0164 & $0.1227^{\star \star \star}$ & $0.0489^{\star \star}$ & 1.0000 & & & & & & \\
\hline Blend & -0.0265 & $0.0613^{* * *}$ & $0.0703^{\star \star \star}$ & $0.0498^{\star \star}$ & 1.0000 & & & & & \\
\hline CabSauv & 0.0357 & $-0.0711^{* * *}$ & $-0.1160^{\star * *}$ & -0.0022 & $-0.0502^{\star *}$ & 1.0000 & & & & \\
\hline Syrah & $-0.0438^{\star *}$ & 0.0166 & 0.0284 & 0.0123 & $-0.2644^{\star * *}$ & -0.0198 & 1.0000 & & & \\
\hline SauvBlanc & -0.0203 & $-0.0654^{* * *}$ & 0.0071 & -0.0117 & $-0.1224^{\star * *}$ & -0.0092 & $-0.0378^{*}$ & 1.0000 & & \\
\hline Chardonnay & -0.0205 & -0.0170 & $0.0444^{* *}$ & -0.0340 & $-0.3138^{\star * *}$ & -0.0235 & $-0.0969 * * *$ & $-0.0449^{* *}$ & 1.0000 & \\
\hline Color & -0.0297 & $0.1017^{\star \star \star}$ & $-0.0626^{* * *}$ & $0.1261^{\star * \star}$ & $0.1601^{\star * \star}$ & $0.0525^{\star *}$ & $0.2165^{\star \star \star}$ & $-0.1745^{\star * *}$ & $-0.4475^{\star * *}$ & 1.0000 \\
\hline \multicolumn{11}{|l|}{ Italy } \\
\hline Reserve & 1.0000 & & & & & & & & & \\
\hline Cap & 0.0032 & 1.0000 & & & & & & & & \\
\hline Origin & $0.0808^{\star * *}$ & $0.0977^{\star \star \star}$ & 1.0000 & & & & & & & \\
\hline Medals & -0.0033 & $0.9454^{\star \star *}$ & 0.0105 & 1.0000 & & & & & & \\
\hline Blend & 0.0163 & $0.0648^{\star * *}$ & $0.0680^{\star * *}$ & $0.0434^{* *}$ & 1.0000 & & & & & \\
\hline CabSauv & $-0.0328^{*}$ & $-0.0562^{\star * *}$ & -0.0277 & -0.0084 & $-0.0804^{* * *}$ & 1.0000 & & & & \\
\hline Syrah & -0.0215 & -0.0140 & $-0.0541^{\star * *}$ & 0.0003 & $-0.0815^{\star \star \star}$ & -0.0143 & 1.0000 & & & \\
\hline SauvBlanc & $-0.0344^{\star}$ & -0.0014 & $-0.0877^{\star * *}$ & -0.0108 & $-0.1368^{\star * *}$ & -0.0240 & -0.0243 & 1.0000 & & \\
\hline Chardonnay & $-0.0554^{\star * *}$ & 0.0175 & $-0.2550^{* * *}$ & $0.0337^{\star}$ & $-0.1517^{\star * \star}$ & -0.0266 & -0.0270 & $-0.0453^{\star \star}$ & 1.0000 & \\
\hline Color & $0.1047^{\star * \star}$ & $0.0458^{* *}$ & $0.1050^{\star \star *}$ & $0.0400^{* *}$ & $0.1463^{\star * \star}$ & $0.1063^{\star * \star}$ & $0.1076^{\star * \star}$ & $-0.2259^{* * *}$ & $-0.2505^{\star * *}$ & 1.0000 \\
\hline \multicolumn{11}{|l|}{ Australia } \\
\hline Reserve & 1.0000 & & & & & & & & & \\
\hline Cap & -0.0077 & 1.0000 & & & & & & & & \\
\hline Origin & $-0.0404^{\star}$ & $-0.4023^{\star \star \star}$ & 1.0000 & & & & & & & \\
\hline Medals & -0.0214 & $0.0947^{\star \star \star}$ & 0.0082 & 1.0000 & & & & & & \\
\hline Blend & $0.0366^{\star}$ & 0.0300 & -0.0071 & -0.0193 & 1.0000 & & & & & \\
\hline CabSauv & -0.0232 & $0.1204^{* * *}$ & 0.0445 & $0.0786^{* * *}$ & $-0.0895^{\star * *}$ & 1.0000 & & & & \\
\hline Syrah & -0.0348 & -0.0138 & $0.2723^{* * *}$ & $0.1274^{\star * *}$ & $-0.1370^{* * *}$ & $-0.2596^{* * *}$ & 1.0000 & & & \\
\hline SauvBlanc & -0.0041 & $-0.1063^{\star * *}$ & $-0.1725^{\star * *}$ & -0.0299 & $-0.0657^{\star * *}$ & $-0.1246^{\star * *}$ & $-0.1908^{\star * *}$ & 1.0000 & & \\
\hline Chardonnay & $0.0413^{\star}$ & $-0.1039^{\star * *}$ & $0.0810^{\star * *}$ & $-0.0645^{\star * *}$ & $-0.0764^{\star * *}$ & $-0.1448^{\star \star *}$ & $-0.2217^{\star \star *}$ & $-0.1064^{\star * *}$ & 1.0000 & \\
\hline Color & -0.0194 & $0.2139^{* * *}$ & $0.0823^{* * *}$ & $0.1272^{\star \star \star}$ & $0.0971^{\star * *}$ & $0.2877^{\star \star \star}$ & $0.4407^{\star * *}$ & $-0.4329^{* * *}$ & $-0.5031^{\star * *}$ & 1.0000 \\
\hline \multicolumn{11}{|l|}{ Germany } \\
\hline Reserve & 1.0000 & & & & & & & & & \\
\hline Cap & $0.0715^{* * *}$ & 1.0000 & & & & & & & & \\
\hline Origin & $-0.0812^{\star * *}$ & $-0.1250^{\star * *}$ & 1.0000 & & & & & & & \\
\hline Medals & $0.0371^{\star}$ & $0.1722^{\star * *}$ & $-0.1564^{\star * *}$ & 1.0000 & & & & & & \\
\hline Blend & $0.1507^{* * *}$ & $0.1241^{\star * *}$ & $-0.1435^{\star * *}$ & $0.0719^{* * *}$ & 1.0000 & & & & & \\
\hline CabSauv & $0.0428^{\star *}$ & $0.0510^{\star * *}$ & $-0.0941^{\star * \star}$ & $0.0500^{\star \star \star}$ & $-0.0933^{* * *}$ & 1.0000 & & & & \\
\hline Syrah & -0.0296 & -0.0229 & $-0.0796^{\star \star *}$ & $0.1012^{\star \star \star}$ & $-0.0752^{\star * *}$ & $-0.0484^{\star \star}$ & 1.0000 & & & \\
\hline SauvBlanc & -0.0243 & $-0.1015^{\star * *}$ & $-0.0371^{\star}$ & 0.0043 & $-0.1037^{* * *}$ & $-0.0668^{\star * *}$ & $-0.0538^{\star * *}$ & 1.0000 & & \\
\hline Chardonnay & -0.0294 & 0.0111 & $-0.0848^{\star * *}$ & -0.0127 & $-0.1195^{\star * *}$ & $-0.0770^{\star \star \star}$ & $-0.0620^{\star *}$ & $-0.0855^{\star \star \star}$ & 1.0000 & \\
\hline Color & $0.0323^{\star}$ & $0.1175^{\star \star \star}$ & $0.0501^{\star \star \star}$ & -0.0244 & $0.0362^{\star}$ & $0.0735^{\star * *}$ & $0.0593^{\star \star \star}$ & $-0.7895^{\star * \star}$ & $0.0942^{\star * *}$ & 1.0000 \\
\hline
\end{tabular}

Notes: 0.90 to 1.00 ( -0.90 to -1.00$)$ Very high positive (negative) correlation; 0.70 to 0.90 ( -0.70 to -0.90$)$ High positive (negative) correlation; 0.50 to 0.70 ( -0.50 to -0.70 ) Moderate positive (negative) correlation; 0.30 to 0.50 ( -0.30 to -0.50 ) Low positive (negative) correlation; 0.00 to 0.30 ( 0.00 to -0.30$)$ negligible correlation (Hinkle, Wiersma, \& Jurs, 2003).

${ }^{* * *},{ }^{* *},{ }^{*}$ stands for significance at $1 \%, 5 \%, 10 \%$, respectively. 
APPENDIX B - STRUCTURAL DIFFERENCES BETWEEN DATASETS

Table B1. Chow test results for the 22 combinations between datasets.

\begin{tabular}{|c|c|}
\hline $\mathrm{H}_{0}$ & Result \\
\hline$\beta_{A}-\beta_{F, G, I}=0$ & $\mathrm{~F}(13,9671)=96.6821 ; \mathrm{p}$-value $=0.0000$ \\
\hline$\beta_{F}-\beta_{A, G, I}=0$ & $\mathrm{~F}(13,9671)=18.6034 ; \mathrm{p}$-value $=0.0000$ \\
\hline$\beta_{G}-\beta_{A, F, I}=0$ & $\mathrm{~F}(13,9671)=78.2422 ; \mathrm{p}$-value $=0.0000$ \\
\hline$\beta_{I^{-}}-\beta_{A, G, F}=0$ & $\mathrm{~F}(13,9671)=61.9454 ; \mathrm{p}$-value $=0.0000$ \\
\hline$\beta_{A}-\beta_{F, I}=0$ & $\mathrm{~F}(13,6985)=59.7917 ; \mathrm{p}$-value $=0.0000$ \\
\hline$\beta_{A}-\beta_{F, G}=0$ & $\mathrm{~F}(13,6859)=86.2516 ; \mathrm{p}$-value $=0.0000$ \\
\hline$\beta_{A}-\beta_{I, G}=0$ & $\mathrm{~F}(13,7551)=122.783 ; \mathrm{p}$-value $=0.0000$ \\
\hline$\beta_{F^{-}} \beta_{A, I}=0$ & $\mathrm{~F}(13,6985)=28.8852 ; \mathrm{p}$-value $=0.0000$ \\
\hline$\beta_{F^{-}} \beta_{A, G}=0$ & $\mathrm{~F}(13,6859)=12.0781 ; \mathrm{p}$-value $=0.0000$ \\
\hline$\beta_{F}-\beta_{I, G}=0$ & $\mathrm{~F}(13,7592)=31.7239 ; \mathrm{p}$-value $=0.0000$ \\
\hline$\beta_{G^{-}} \beta_{A, I}=0$ & $\mathrm{~F}(13,7551)=91.5821 ; \mathrm{p}$-value $=0.0000$ \\
\hline$\beta_{G^{-}} \beta_{A, F}=0$ & $\mathrm{~F}(13,6859)=69.2847 ; \mathrm{p}$-value $=0.0000$ \\
\hline$\beta_{G^{-}} \beta_{I, F}=0$ & $\mathrm{~F}(13,7592)=27.6741 ; \mathrm{p}$-value $=0.0000$ \\
\hline$\beta_{I^{-}} \beta_{A, F}=0$ & $\mathrm{~F}(13,6985)=53.9544 ; \mathrm{p}$-value $=0.0000$ \\
\hline$\beta_{I^{-}} \beta_{A, G}=0$ & $\mathrm{~F}(13,7551)=50.6602 ; \mathrm{p}$-value $=0.0000$ \\
\hline$\beta_{I^{-}} \beta_{F, G}=0$ & $\mathrm{~F}(13,7592)=51.5812 ; \mathrm{p}$-value $=0.0000$ \\
\hline$\beta_{A}-\beta_{F}=0$ & $\mathrm{~F}(13,4173)=44.0896 ; \mathrm{p}$-value $=0.0000$ \\
\hline$\beta_{A}-\beta_{G}=0$ & $\mathrm{~F}(13,4739)=100.381 ; \mathrm{p}$-value $=0.0000$ \\
\hline$\beta_{A}-\beta_{I}=0$ & $\mathrm{~F}(13,4865)=76.3607 ; \mathrm{p}$-value $=0.0000$ \\
\hline$\beta_{F^{-}} \beta_{I}=0$ & $\mathrm{~F}(13,4906)=33.0689 ; \mathrm{p}$-value $=0.0000$ \\
\hline$\beta_{F^{-}} \beta_{G}=0$ & $\mathrm{~F}(13,4780)=15.4393 ; \mathrm{p}$-value $=0.0000$ \\
\hline$\beta_{G^{-}} \beta_{I}=0$ & $\mathrm{~F}(13,5472)=31.7139 ; \mathrm{p}$-value $=0.0000$ \\
\hline
\end{tabular}

Notes: A = Australia; $\mathrm{G}=$ Germany; $\mathrm{I}=$ Italy; $\mathrm{F}$ = France.
Table B2. Show test results between wine color.

\begin{tabular}{lll}
\hline Data & $\mathrm{H}_{0}$ & Result \\
\hline Pooled data & $\beta_{R}-\beta_{W}=0$ & $\mathrm{~F}(8,9681)=12,3703 ; \mathrm{p}$-value $=0.0000$ \\
Australia & $\beta_{R}-\beta_{W}=0$ & $\mathrm{~F}(8,2047)=9,03773 ; \mathrm{p}$-value $=0.0000$ \\
Germany & $\beta_{R}-\beta_{W}=0$ & $\mathrm{~F}(8,2648)=5,03464 ; \mathrm{p}$-value $=0.0000$ \\
France & $\beta_{R}-\beta_{W}=0$ & $\mathrm{~F}(8,2078)=4,60065 ; \mathrm{p}$-value $=0.0000$ \\
Italy & $\beta_{R}-\beta_{W}=0$ & $\mathrm{~F}(8,2787)=5,6072 ; \mathrm{p}$-value $=0.0000$ \\
\hline
\end{tabular}

Notes: $\mathrm{R}=$ Red; $\mathrm{W}=$ White. 


\section{APPENDIX C - INTERQUANTILE DIFFERENCES TESTS BY COUNTRIES}

Table C1. Australia.

\begin{tabular}{|c|c|c|c|}
\hline Variable & 25-75 quantiles & 25-50 quantiles & 50-75 quantiles \\
\hline Cap & $\begin{array}{c}F(1,2050)=4.30 \\
\text { Prob }>F=0.038^{\star *}\end{array}$ & $\begin{array}{c}\mathrm{F}(1,2050)=10.86 \\
\text { Prob }>\mathrm{F}=0.001^{* * *}\end{array}$ & $\begin{array}{l}F(1,2050)=0.15 \\
\text { Prob }>F=0.701\end{array}$ \\
\hline Reserve & $\begin{array}{l}F(1,2050)=0.10 \\
\text { Prob }>F=0.755\end{array}$ & $\begin{array}{l}\mathrm{F}(1,2050)=1.09 \\
\text { Prob }>\mathrm{F}=0.297\end{array}$ & $\begin{array}{l}F(1,2050)=0.97 \\
\text { Prob }>F=0.325\end{array}$ \\
\hline Color & $\begin{array}{c}\mathrm{F}(1,2050)=31.29 \\
\text { Prob }>\mathrm{F}=0.000^{* * *}\end{array}$ & $\begin{array}{c}F(1,2050)=9.46 \\
\text { Prob }>F=0.002^{* * *}\end{array}$ & $\begin{array}{c}F(1,2050)=29.69 \\
\text { Prob }>F=0.000^{* * *}\end{array}$ \\
\hline Age & $\begin{array}{c}F(1,2050)=5.01 \\
\text { Prob }>F=0.025^{\star *}\end{array}$ & $\begin{array}{c}F(1,2050)=4.84 \\
\text { Prob }>F=0.028^{\star *}\end{array}$ & $\begin{array}{l}F(1,2050)=2.63 \\
\text { Prob }>F=0.105\end{array}$ \\
\hline Origin & $\begin{array}{c}F(1,2050)=14.59 \\
\text { Prob }>F=0.000^{* * *}\end{array}$ & $\begin{array}{c}F(1,2050)=14.23 \\
\text { Prob }>F=0.000^{* * *}\end{array}$ & $\begin{array}{l}F(1,2050)=1.69 \\
\text { Prob }>F=0.194\end{array}$ \\
\hline Medals & $\begin{array}{c}F(1,2050)=15.29 \\
\text { Prob }>F=0.000^{\star * *}\end{array}$ & $\begin{array}{c}F(1,2050)=7.03 \\
\text { Prob }>F=0.005^{\star * *}\end{array}$ & $\begin{array}{c}\mathrm{F}(1,2050)=4.39 \\
\text { Prob }>\mathrm{F}=0.036^{* *}\end{array}$ \\
\hline Alcohol & $\begin{array}{l}F(1,2050)=2.64 \\
\text { Prob }>F=0.104\end{array}$ & $\begin{array}{l}F(1,2050)=0.11 \\
\text { Prob }>F=0.737\end{array}$ & $\begin{array}{l}F(1,2050)=2.28 \\
\text { Prob }>F=0.131\end{array}$ \\
\hline Blend & $\begin{array}{l}F(1,2050)=0.17 \\
\text { Prob }>F=0.676\end{array}$ & $\begin{array}{l}F(1,2050)=0.00 \\
\text { Prob }>F=0.963\end{array}$ & $\begin{array}{l}F(1,2050)=0.30 \\
\text { Prob }>F=0.582\end{array}$ \\
\hline Cabernet Sauvignon & $\begin{array}{l}F(1,2050)=0.71 \\
\text { Prob }>F=0.3986\end{array}$ & $\begin{array}{l}F(1,2050)=0.03 \\
\text { Prob }>F=0.864\end{array}$ & $\begin{array}{c}F(1,2050)=0.92 \\
\text { Prob }>F=0.338\end{array}$ \\
\hline Syrah & $\begin{array}{l}F(1,2050)=1.47 \\
\text { Prob }>F=0.225\end{array}$ & $\begin{array}{c}\mathrm{F}(1,2050)=0.02 \\
\text { Prob }>\mathrm{F}=0.889\end{array}$ & $\begin{array}{l}F(1,2050)=2.24 \\
\text { Prob }>F=0.135\end{array}$ \\
\hline Sauvignon Blanc & $\begin{array}{c}F(1,2050)=0.47 \\
\text { Prob }>F=0.4918\end{array}$ & $\begin{array}{l}F(1,2050)=1.95 \\
\text { Prob }>F=0.162\end{array}$ & $\begin{array}{l}F(1,2050)=0.07 \\
\text { Prob }>F=0.786\end{array}$ \\
\hline Chardonnay & $\begin{array}{c}F(1,2050)=18.75 \\
\text { Prob }>F=0.000^{\star * *}\end{array}$ & $\begin{array}{c}F(1,2050)=14.90 \\
\text { Prob }>F=0.000^{* * *}\end{array}$ & $\begin{array}{l}F(1,2050)=5.89 \\
\text { Prob }>F=0.015^{\star \star}\end{array}$ \\
\hline
\end{tabular}

${ }^{* * *},{ }^{* *},{ }^{*}$ stands for significance at $1 \%, 5 \%, 10 \%$, respectively. 
Table C2. Germany.

\begin{tabular}{|c|c|c|c|}
\hline Variable & 25-75 quantiles & 25-50 quantiles & 50-75 quantiles \\
\hline Cap & $\begin{array}{l}F(1,2651)=2.00 \\
\text { Prob }>F=0.158\end{array}$ & $\begin{array}{l}F(1,2651)=3.81 \\
\text { Prob }>F=0.051^{\star}\end{array}$ & $\begin{array}{l}F(1,2651)=0.01 \\
\text { Prob }>F=0.927\end{array}$ \\
\hline Reserve & $\begin{array}{c}F(1,2651)=14.71 \\
\text { Prob }>F=0.000^{\star * *}\end{array}$ & $\begin{array}{l}\mathrm{F}(1,2651)=17.53 \\
\text { Prob }>\mathrm{F}=0.000^{* * *}\end{array}$ & $\begin{array}{l}\mathrm{F}(1,2651)=3.08 \\
\text { Prob }>\mathrm{F}=0.079^{\star}\end{array}$ \\
\hline Color & $\begin{array}{l}F(1,2651)=0.22 \\
\text { Prob }>F=0.638\end{array}$ & $\begin{array}{l}F(1,2651)=1.40 \\
\text { Prob }>F=0.236\end{array}$ & $\begin{array}{l}F(1,2651)=0.05 \\
\text { Prob }>F=0.819\end{array}$ \\
\hline Age & $\begin{array}{c}\mathrm{F}(1,2651)=36.59 \\
\text { Prob }>\mathrm{F}=0.000^{* * *}\end{array}$ & $\begin{array}{c}\mathrm{F}(1,2651)=18.80 \\
\text { Prob }>\mathrm{F}=0.000^{* * *}\end{array}$ & $\begin{array}{c}\mathrm{F}(1,2651)=12.80 \\
\text { Prob }>\mathrm{F}=0.000^{* * *}\end{array}$ \\
\hline Origin & $\begin{array}{c}F(1,2651)=7.26 \\
\text { Prob }>F=0.007^{\star * *}\end{array}$ & $\begin{array}{c}F(1,2651)=26.24 \\
\text { Prob }>F=0.000^{* * *}\end{array}$ & $\begin{array}{l}F(1,2651)=0.53 \\
\text { Prob }>F=0.470\end{array}$ \\
\hline Medals & $\begin{array}{l}F(1,2651)=0.09 \\
\text { Prob }>F=0.769\end{array}$ & $\begin{array}{l}F(1,2651)=0.10 \\
\text { Prob }>F=0.750\end{array}$ & $\begin{array}{l}F(1,2651)=0.00 \\
\text { Prob }>F=0.962\end{array}$ \\
\hline Alcohol & $\begin{array}{l}F(1,2651)=0.14 \\
\text { Prob }>F=0.707\end{array}$ & $\begin{array}{l}F(1,2651)=1.48 \\
\text { Prob }>F=0.224\end{array}$ & $\begin{array}{l}F(1,2651)=0.28 \\
\text { Prob }>F=0.600\end{array}$ \\
\hline Blend & $\begin{array}{l}F(1,2651)=0.21 \\
\text { Prob }>F=0.643\end{array}$ & $\begin{array}{l}F(1,2651)=0.01 \\
\text { Prob }>F=0.937\end{array}$ & $\begin{array}{l}F(1,2651)=0.43 \\
\text { Prob }>F=0.510\end{array}$ \\
\hline Cabernet Sauvignon & $\begin{array}{l}F(1,2651)=0.13 \\
\text { Prob }>F=0.714\end{array}$ & $\begin{array}{l}F(1,2651)=0.00 \\
\text { Prob }>F=0.947\end{array}$ & $\begin{array}{c}F(1,2651)=0.15 \\
\text { Prob }>F=0.697\end{array}$ \\
\hline Syrah & $\begin{array}{l}F(1,2651)=0.07 \\
\text { Prob }>F=0.791\end{array}$ & $\begin{array}{l}F(1,2651)=0.17 \\
\text { Prob }>F=0.678\end{array}$ & $\begin{array}{l}F(1,2651)=0.51 \\
\text { Prob }>F=0.476\end{array}$ \\
\hline Sauvignon Blanc & $\begin{array}{l}F(1,2651)=3.58 \\
\text { Prob }>F=0.058^{*}\end{array}$ & $\begin{array}{l}F(1,2651)=6.13 \\
\text { Prob }>F=0.013^{\star *}\end{array}$ & $\begin{array}{l}F(1,2651)=0.26 \\
\text { Prob }>F=0.613\end{array}$ \\
\hline Chardonnay & $\begin{array}{c}F(1,2651)=4.72 \\
\text { Prob }>F=0.029^{* *}\end{array}$ & $\begin{array}{l}F(1,2651)=0.17 \\
\text { Prob }>F=0.680\end{array}$ & $\begin{array}{l}F(1,2651)=3.80 \\
\text { Prob }>F=0.052^{*}\end{array}$ \\
\hline
\end{tabular}

${ }^{* * *},{ }^{* *},{ }^{*}$ stands for significance at $1 \%, 5 \%, 10 \%$, respectively.

Table C3. France.

\begin{tabular}{|c|c|c|c|}
\hline Variable & $25-75$ quantiles & $25-50$ quantiles & $50-75$ quantiles \\
\hline Cap & $\begin{array}{l}F(1,2081)=1.09 \\
\text { Prob }>F=0.296\end{array}$ & $\begin{array}{l}F(1,2081)=0.46 \\
\text { Prob }>F=0.499\end{array}$ & $\begin{array}{l}F(1,2081)=1.53 \\
\text { Prob }>F=0.218\end{array}$ \\
\hline Reserve & $\begin{array}{l}F(1,2081)=1.77 \\
\text { Prob }>F=0.183\end{array}$ & $\begin{array}{l}F(1,2081)=0.49 \\
\text { Prob }>F=0.483\end{array}$ & $\begin{array}{l}F(1,2081)=1.20 \\
\text { Prob }>F=0.274\end{array}$ \\
\hline Color & $\begin{array}{l}F(1,2081)=0.85 \\
\text { Prob }>F=0.355\end{array}$ & $\begin{array}{l}F(1,2081)=0.70 \\
\text { Prob }>F=0.404\end{array}$ & $\begin{array}{l}F(1,2081)=0.11 \\
\text { Prob }>F=0.737\end{array}$ \\
\hline Age & $\begin{array}{l}\mathrm{F}(1,2081)=45.40 \\
\text { Prob }>\mathrm{F}=0.000^{* * *}\end{array}$ & $\begin{array}{c}\mathrm{F}(1,2081)=23.15 \\
\text { Prob }>\mathrm{F}=0.000^{\star * *}\end{array}$ & $\begin{array}{c}\mathrm{F}(1,2081)=6.64 \\
\text { Prob }>\mathrm{F}=0.010^{* * *}\end{array}$ \\
\hline Origin & $\begin{array}{l}F(1,2081)=1.54 \\
\text { Prob }>F=0.214\end{array}$ & $\begin{array}{l}F(1,2081)=2.29 \\
\text { Prob }>F=0.130\end{array}$ & $\begin{array}{l}F(1,2081)=0.06 \\
\text { Prob }>F=0.802\end{array}$ \\
\hline Medals & $\begin{array}{l}F(1,2081)=3.23 \\
\text { Prob }>F=0.072^{*}\end{array}$ & $\begin{array}{l}F(1,2081)=3.00 \\
\text { Prob }>F=0.084^{*}\end{array}$ & $\begin{array}{l}F(1,2081)=1.39 \\
\text { Prob }>F=0.238\end{array}$ \\
\hline Alcohol & $\begin{array}{c}\mathrm{F}(1,2081)=4.93 \\
\text { Prob }>\mathrm{F}=0.027^{\star *}\end{array}$ & $\begin{array}{c}F(1,2081)=8.54 \\
\text { Prob }>F=0.004^{* * *}\end{array}$ & $\begin{array}{l}F(1,2081)=0.46 \\
\text { Prob }>F=0.499\end{array}$ \\
\hline Blend & $\begin{array}{c}F(1,2081)=6.51 \\
\text { Prob }>F=0.011^{* *}\end{array}$ & $\begin{array}{c}\mathrm{F}(1,2081)=5.04 \\
\text { Prob }>\mathrm{F}=0.025^{* *}\end{array}$ & $\begin{array}{l}F(1,2081)=1.25 \\
\text { Prob }>F=0.263\end{array}$ \\
\hline Cabernet Sauvignon & $\begin{array}{l}F(1,2081)=0.05 \\
\text { Prob }>F=0.827\end{array}$ & $\begin{array}{l}F(1,2081)=0.30 \\
\text { Prob }>F=0.581\end{array}$ & $\begin{array}{l}F(1,2081)=1.14 \\
\text { Prob }>F=0.285\end{array}$ \\
\hline Syrah & $\begin{array}{l}F(1,2081)=1.98 \\
\text { Prob }>F=0.159\end{array}$ & $\begin{array}{l}\mathrm{F}(1,2081)=3.88 \\
\text { Prob }>\mathrm{F}=0.049^{* *}\end{array}$ & $\begin{array}{l}F(1,2081)=0.01 \\
\text { Prob }>F=0.903\end{array}$ \\
\hline Sauvignon Blanc & $\begin{array}{c}F(1,2081)=9.66 \\
\text { Prob }>F=0.002^{* * *}\end{array}$ & $\begin{array}{l}F(1,2081)=1.08 \\
\text { Prob }>F=0.299\end{array}$ & $\begin{array}{l}F(1,2081)=6.51 \\
\text { Prob }>F=0.011^{* *}\end{array}$ \\
\hline Chardonnay & $\begin{array}{l}F(1,2081)=0.04 \\
\text { Prob }>F=0.840\end{array}$ & $\begin{array}{l}F(1,2081)=0.02 \\
\text { Prob }>F=0.901\end{array}$ & $\begin{array}{l}F(1,2081)=0.01 \\
\text { Prob }>F=0.913\end{array}$ \\
\hline
\end{tabular}

$* * *,{ }^{* *},{ }^{*}$ stands for significance at $1 \%, 5 \%, 10 \%$, respectively. 
Table C4. Italy.

\begin{tabular}{|c|c|c|c|}
\hline Variable & 25-75 quantiles & 25-50 quantiles & 50-75 quantiles \\
\hline Cap & $\begin{array}{l}F(1,2790)=0.17 \\
\text { Prob }>F=0.685\end{array}$ & $\begin{array}{l}F(1,2790)=0.38 \\
\text { Prob }>F=0.539\end{array}$ & $\begin{array}{l}F(1,2790)=0.00 \\
\text { Prob }>F=0.983\end{array}$ \\
\hline Reserve & $\begin{array}{l}F(1,2790)=3.00 \\
\text { Prob }>F=0.083^{\star}\end{array}$ & $\begin{array}{l}F(1,2790)=0.04 \\
\text { Prob }>F=0.850\end{array}$ & $\begin{array}{l}\mathrm{F}(1,2790)=3.61 \\
\text { Prob }>\mathrm{F}=0.057^{\star}\end{array}$ \\
\hline Color & $\begin{array}{l}F(1,2790)=0.86 \\
\text { Prob }>F=0.355\end{array}$ & $\begin{array}{l}F(1,2790)=0.93 \\
\text { Prob }>F=0.334\end{array}$ & $\begin{array}{l}\mathrm{F}(1,2790)=3.04 \\
\text { Prob }>\mathrm{F}=0.081^{*}\end{array}$ \\
\hline Age & $\begin{array}{c}\mathrm{F}(1,2790)=14.96 \\
\text { Prob }>\mathrm{F}=0.000^{* * *}\end{array}$ & $\begin{array}{c}\mathrm{F}(1,2790)=12.34 \\
\text { Prob }>\mathrm{F}=0.001^{\star * *}\end{array}$ & $\begin{array}{c}\mathrm{F}(1,2790)=4.61 \\
\text { Prob }>\mathrm{F}=0.032^{\star \star}\end{array}$ \\
\hline Origin & $\begin{array}{c}\mathrm{F}(1,2790)=23.44 \\
\text { Prob }>\mathrm{F}=0.000^{\star * *}\end{array}$ & $\begin{array}{c}F(1,2790)=31.12 \\
\text { Prob }>F=0.000^{* *}\end{array}$ & $\begin{array}{c}F(1,2790)=6.79 \\
\text { Prob }>F=0.009^{* * *}\end{array}$ \\
\hline Medals & $\begin{array}{l}F(1,2790)=0.00 \\
\text { Prob }>F=0.998\end{array}$ & $\begin{array}{l}F(1,2790)=0.13 \\
\text { Prob }>F=0.714\end{array}$ & $\begin{array}{l}F(1,2790)=0.05 \\
\text { Prob }>F=0.828\end{array}$ \\
\hline Alcohol & $\begin{array}{l}F(1,2790)=1.07 \\
\text { Prob }>F=0.300\end{array}$ & $\begin{array}{l}F(1,2790)=0.53 \\
\text { Prob }>F=0.469\end{array}$ & $\begin{array}{l}\mathrm{F}(1,2790)=0.59 \\
\text { Prob }>\mathrm{F}=0.441\end{array}$ \\
\hline Blend & $\begin{array}{l}F(1,2790)=0.68 \\
\text { Prob }>F=0.409\end{array}$ & $\begin{array}{l}F(1,2790)=0.05 \\
\text { Prob }>F=0.827\end{array}$ & $\begin{array}{l}\mathrm{F}(1,2790)=0.49 \\
\text { Prob }>\mathrm{F}=0.484\end{array}$ \\
\hline Cabernet Sauvignon & $\begin{array}{l}F(1,2790)=1.24 \\
\text { Prob }>F=0.265\end{array}$ & $\begin{array}{c}\mathrm{F}(1,2790)=0.43 \\
\text { Prob }>\mathrm{F}=0.514\end{array}$ & $\begin{array}{c}F(1,2790)=1.16 \\
\text { Prob }>F=0.281\end{array}$ \\
\hline Syrah & $\begin{array}{l}\mathrm{F}(1,2790)=0.00 \\
\text { Prob }>\mathrm{F}=0.954\end{array}$ & $\begin{array}{l}F(1,2790)=0.04 \\
\text { Prob }>F=0.838\end{array}$ & $\begin{array}{l}F(1,2790)=0.01 \\
\text { Prob }>F=0.940\end{array}$ \\
\hline Sauvignon Blanc & $\begin{array}{c}\mathrm{F}(1,2790)=16.32 \\
\text { Prob }>\mathrm{F}=0.000^{* * *}\end{array}$ & $\begin{array}{l}\mathrm{F}(1,2790)=0.29 \\
\text { Prob }>\mathrm{F}=0.593\end{array}$ & $\begin{array}{c}F(1,2790)=22.3 \\
\text { Prob }>F=0.000^{* * *}\end{array}$ \\
\hline Chardonnay & $\begin{array}{c}\mathrm{F}(1,2790)=15.54 \\
\text { Prob }>\mathrm{F}=0.000^{* * *}\end{array}$ & $\begin{array}{c}\mathrm{F}(1,2790)=8.14 \\
\text { Prob }>\mathrm{F}=0.004^{* * *}\end{array}$ & $\begin{array}{l}\mathrm{F}(1,2790)=5.45 \\
\text { Prob }>\mathrm{F}=0.020^{\star *}\end{array}$ \\
\hline
\end{tabular}

$* * *, * *,{ }^{*}$ stands for significance at $1 \%, 5 \%, 10 \%$, respectively. 
APPENDIX D - QUANTILE REGRESSION RESULTS BY COLOR FOR EACH COUNTRY

Table D1. Australia.

\begin{tabular}{|c|c|c|c|c|c|c|c|c|}
\hline & \multicolumn{4}{|c|}{ Red } & \multicolumn{4}{|c|}{ White } \\
\hline & 25-quantile ${ }^{\mathrm{a}}$ & 50-quantile ${ }^{\mathrm{a}}$ & 75-quantile ${ }^{\mathrm{a}}$ & $\mathrm{OLS}^{\mathrm{b}}$ & 25-quantile $\mathrm{e}^{\mathrm{a}}$ & 50-quantile ${ }^{\mathrm{a}}$ & 75-quantile $\mathrm{a}^{\mathrm{a}}$ & $\mathrm{OLS}^{\mathrm{b}}$ \\
\hline Reserve & $\begin{array}{c}0.159 \\
(0.120)\end{array}$ & $\begin{array}{c}0.081 \\
(0.102)\end{array}$ & $\begin{array}{c}0.062 \\
(0.131)\end{array}$ & $\begin{array}{c}0.715 \\
(0.081)\end{array}$ & $\begin{array}{c}0.103 \\
(0.063)\end{array}$ & $\begin{array}{c}0.045 \\
(0.097)\end{array}$ & $\begin{array}{c}0.128 \\
(0.032)\end{array}$ & $\begin{array}{l}0.104^{*} \\
(0.061)\end{array}$ \\
\hline Closure & $\begin{array}{c}0.406^{* * *} \\
(0.031)\end{array}$ & $\begin{array}{c}0.469^{* * *} \\
(0.030)\end{array}$ & $\begin{array}{c}0.468^{* * *} \\
(0.047)\end{array}$ & $\begin{array}{c}0.450^{* * *} \\
(0.027)\end{array}$ & $\begin{array}{c}0.253^{\star * *} \\
(0.052)\end{array}$ & $\begin{array}{c}0.285^{\star * *} \\
(0.050)\end{array}$ & $\begin{array}{c}0.367^{\star * *} \\
(0.015)\end{array}$ & $\begin{array}{c}0.299^{* * *} \\
(0.050)\end{array}$ \\
\hline Wine origin & $\begin{array}{l}0.076^{* *} \\
(0.037)\end{array}$ & $\begin{array}{c}-0.052 \\
(0.048)\end{array}$ & $\begin{array}{l}-0.124^{* *} \\
(0.055)\end{array}$ & $-0.024(0.024)$ & $\begin{array}{c}0.017 \\
(0.020)\end{array}$ & $\begin{array}{l}-0.001 \\
(0.009)\end{array}$ & $\begin{array}{l}-0.002 \\
(0.018)\end{array}$ & $\begin{array}{l}-0.015 \\
(0.018)\end{array}$ \\
\hline Age & $\begin{array}{l}0.016^{* *} \\
(0.007)\end{array}$ & $\begin{array}{c}0.023^{\star * *} \\
(0.004)\end{array}$ & $\begin{array}{c}0.032^{\star * *} \\
(0.005)\end{array}$ & $\begin{array}{c}0.022^{\star * *} \\
(0.004)\end{array}$ & $\begin{array}{c}0.006 \\
(0.004)\end{array}$ & $\begin{array}{c}0.005 \\
(0.004)\end{array}$ & $\begin{array}{c}0.014 \\
(0.009)\end{array}$ & $\begin{array}{c}0.017^{\star * *} \\
(0.005)\end{array}$ \\
\hline Awards or medals & $\begin{array}{c}0.113^{\star * *} \\
(0.032)\end{array}$ & $\begin{array}{c}0.165^{\star * *} \\
(0.042)\end{array}$ & $\begin{array}{c}0.240^{* * *} \\
(0.031)\end{array}$ & $\begin{array}{c}0.193^{* * *} \\
(0.027)\end{array}$ & $\begin{array}{l}0.041^{\star *} \\
(0.024)\end{array}$ & $\begin{array}{c}0.077 \\
(0.049)\end{array}$ & $\begin{array}{l}0.059^{*} \\
(0.036)\end{array}$ & $\begin{array}{l}0.085^{\star *} \\
(0.034)\end{array}$ \\
\hline AlcCont & $\begin{array}{c}0.050^{* * *} \\
(0.016)\end{array}$ & $\begin{array}{c}0.048^{\star * *} \\
(0.018)\end{array}$ & $\begin{array}{l}0.051^{\star *} \\
(0.024)\end{array}$ & $\begin{array}{l}0.032^{\star *} \\
(0.014)\end{array}$ & $\begin{array}{c}0.022^{\star * *} \\
(0.008)\end{array}$ & $\begin{array}{c}0.011 \\
(0.011)\end{array}$ & $\begin{array}{c}0.001 \\
(0.012)\end{array}$ & $\begin{array}{l}0.025^{\star *} \\
(0.011)\end{array}$ \\
\hline Blend & $\begin{array}{c}-0.101^{\star * *} \\
(0.036)\end{array}$ & $\begin{array}{c}-0.073^{\star * \star} \\
(0.028)\end{array}$ & $\begin{array}{l}-0.078^{\star} \\
(0.045)\end{array}$ & $-0.049(0.035)$ & $\begin{array}{l}-0.083 \\
(0.070)\end{array}$ & $\begin{array}{l}-0.034 \\
(0.101)\end{array}$ & $\begin{array}{c}0.145 \\
(0.124)\end{array}$ & $\begin{array}{c}0.009 \\
(0.077)\end{array}$ \\
\hline Cabernet Sauvignon & $\begin{array}{l}-0.054 \\
(0.034)\end{array}$ & $\begin{array}{l}-0.047 \\
(0.030)\end{array}$ & $\begin{array}{l}-0.037 \\
(0.034)\end{array}$ & $-0.003(0.025)$ & & & & \\
\hline Syrah & $\begin{array}{l}-0.025 \\
(0.023)\end{array}$ & $\begin{array}{c}-0.005 \\
(0.025)\end{array}$ & $\begin{array}{c}0.020 \\
(0.042)\end{array}$ & $\begin{array}{l}0.044^{* *} \\
(0.022)\end{array}$ & & & & \\
\hline Sauvignon Blanc & & & & & $\begin{array}{c}-0.061^{* * *} \\
(0.019)\end{array}$ & $\begin{array}{c}-0.066^{* * *} \\
(0.020)\end{array}$ & $\begin{array}{l}-0.055^{* *} \\
(0.022)\end{array}$ & $\begin{array}{c}-0.074^{* * *} \\
(0.018)\end{array}$ \\
\hline Chardonnay & & & & & $\begin{array}{c}0.009 \\
(0.020)\end{array}$ & $\begin{array}{c}0.069^{* * *} \\
(0.024)\end{array}$ & $\begin{array}{c}0.167^{* * *} \\
(0.040)\end{array}$ & $\begin{array}{c}0.087^{* * *} \\
(0.021)\end{array}$ \\
\hline Constant & $\begin{array}{c}0.279 \\
(0.228)\end{array}$ & $\begin{array}{c}0.514^{\star * *} \\
(0.250)\end{array}$ & $\begin{array}{l}0.671^{\star *} \\
(0.336)\end{array}$ & $\begin{array}{c}0.715^{\star * *} \\
(0.194)\end{array}$ & $\begin{array}{c}0.674^{\star * *} \\
(0.119)\end{array}$ & $\begin{array}{c}0.928 \\
(0.155)\end{array}$ & $\begin{array}{l}1.112^{\star * *} \\
(0.152)\end{array}$ & $\begin{array}{c}0.721^{\star * *} \\
(0.150)\end{array}$ \\
\hline Observations & \multicolumn{4}{|c|}{1386} & \multicolumn{4}{|c|}{677} \\
\hline R-squared & 0.14 & 0.24 & 0.30 & 0.42 & 0.06 & 0.09 & 0.17 & 0.23 \\
\hline
\end{tabular}

${ }^{*},{ }^{* *},{ }^{* *}$ denotes significance at $10 \%, 5 \%, 1 \%$.

aBootstrap standard errors in parentheses; Replications $=1000$.

${ }^{b}$ Robust standard errors in parentheses; OLS = ordinary least squares, included as reference.

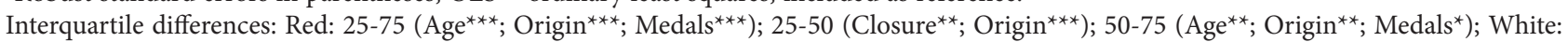
25-75 (Chardonnay ${ }^{* * *}$ ); 25-50 (Chardonnay ${ }^{* * *}$ ); 50-75 (Chardonnay ${ }^{\star * *}$ ). 
Table D2. Germany.

\begin{tabular}{|c|c|c|c|c|c|c|c|c|}
\hline & \multicolumn{4}{|c|}{ Red } & \multicolumn{4}{|c|}{ White } \\
\hline & 25-quantile ${ }^{a}$ & 50-quantile ${ }^{\mathrm{a}}$ & 75-quantile ${ }^{a}$ & OLS $^{\mathrm{b}}$ & 25-quantile ${ }^{a}$ & 50-quantile ${ }^{\mathrm{a}}$ & 75-quantile ${ }^{a}$ & OLS $^{\mathrm{b}}$ \\
\hline Reserve & $\begin{array}{l}-0.012 \\
(0.020)\end{array}$ & $\begin{array}{c}-0.083^{* * *} \\
(0.029)\end{array}$ & $\begin{array}{c}-0.127^{* * *} \\
(0.029)\end{array}$ & $\begin{array}{c}-0.089^{* * *} \\
(0.021)\end{array}$ & $\begin{array}{c}-0.096^{* * *} \\
(0.036)\end{array}$ & $\begin{array}{c}-0.118^{\star *} \\
(0.053)\end{array}$ & $\begin{array}{c}-0.252^{* * *} \\
(0.057)\end{array}$ & $\begin{array}{c}-0.181^{\star * *} \\
(0.035)\end{array}$ \\
\hline Closure & $\begin{array}{l}-0.024^{*} \\
(0.014)\end{array}$ & $\begin{array}{c}-0.058^{* * *} \\
(0.020)\end{array}$ & $\begin{array}{c}-0.050^{* * *} \\
(0.019)\end{array}$ & $\begin{array}{c}-0.052^{* * *} \\
(0.011)\end{array}$ & $\begin{array}{c}0.044 \\
(0.042)\end{array}$ & $\begin{array}{c}0.039 \\
(0.031)\end{array}$ & $\begin{array}{c}0.021 \\
(0.035)\end{array}$ & $\begin{array}{c}0.010 \\
(0.023)\end{array}$ \\
\hline Wine origin & $\begin{array}{c}0.060^{\star * *} \\
(0.016)\end{array}$ & $\begin{array}{c}0.003 \\
(0.018)\end{array}$ & $\begin{array}{c}0.010 \\
(0.015)\end{array}$ & $\begin{array}{l}0.032^{\star *} \\
(0.014)\end{array}$ & $\begin{array}{c}0.040 \\
(0.035)\end{array}$ & $\begin{array}{c}0.007 \\
(0.041)\end{array}$ & $\begin{array}{c}-0.054^{* *} \\
(0.024)\end{array}$ & $\begin{array}{l}-0.024 \\
(0.031)\end{array}$ \\
\hline Age & $\begin{array}{c}0.057^{* * *} \\
(0.005)\end{array}$ & $\begin{array}{c}0.075^{\star * *} \\
(0.003)\end{array}$ & $\begin{array}{c}0.084^{* * *} \\
(0.003)\end{array}$ & $\begin{array}{c}0.064^{* * *} \\
(0.003)\end{array}$ & $\begin{array}{c}0.069^{* * *} \\
(0.013)\end{array}$ & $\begin{array}{c}0.097^{* * *} \\
(0.013)\end{array}$ & $\begin{array}{c}0.099^{* * *} \\
(0.023)\end{array}$ & $\begin{array}{c}0.081^{* * *} \\
(0.010)\end{array}$ \\
\hline Awards or medals & $\begin{array}{c}0.097^{* * *} \\
(0.012)\end{array}$ & $\begin{array}{c}0.107^{* * *} \\
(0.019)\end{array}$ & $\begin{array}{c}0.129^{* * *} \\
(0.016)\end{array}$ & $\begin{array}{c}0.113^{* * *} \\
(0.011)\end{array}$ & $\begin{array}{l}0.068^{* *} \\
(0.029)\end{array}$ & $\begin{array}{c}0.085^{* * *} \\
(0.031)\end{array}$ & $\begin{array}{c}-0.007 \\
(0.031)\end{array}$ & $\begin{array}{l}0.034^{*} \\
(0.021)\end{array}$ \\
\hline AlcCont & $\begin{array}{c}0.075^{\star * *} \\
(0.009)\end{array}$ & $\begin{array}{c}0.064^{* * *} \\
(0.008)\end{array}$ & $\begin{array}{c}0.078^{* * *} \\
(0.006)\end{array}$ & $\begin{array}{c}0.084^{\star * *} \\
(0.007)\end{array}$ & $\begin{array}{c}0.078^{\star * *} \\
(0.023)\end{array}$ & $\begin{array}{c}0.059^{* * *} \\
(0.020)\end{array}$ & $\begin{array}{c}0.057^{* * *} \\
(0.022)\end{array}$ & $\begin{array}{c}0.067^{* * *} \\
(0.015)\end{array}$ \\
\hline Blend & $\begin{array}{c}-0.046^{* *} \\
(0.021)\end{array}$ & $\begin{array}{l}-0.044^{*} \\
(0.024)\end{array}$ & $\begin{array}{l}-0.041^{*} \\
(0.024)\end{array}$ & $-0.020(0.017)$ & $\begin{array}{c}0.107 \\
(0.095)\end{array}$ & $\begin{array}{l}0.132^{*} \\
(0.071)\end{array}$ & $\begin{array}{l}0.217^{\star *} \\
(0.040)\end{array}$ & $\begin{array}{c}0.163^{* * *} \\
(0.063)\end{array}$ \\
\hline Cabernet Sauvignon & $\begin{array}{c}-0.062^{* * *} \\
(0.017)\end{array}$ & $\begin{array}{c}-0.073^{\star * *} \\
(0.016)\end{array}$ & $\begin{array}{c}-0.097^{* * *} \\
(0.030)\end{array}$ & $\begin{array}{c}-0.071^{* * *} \\
(0.022)\end{array}$ & & & & \\
\hline Syrah & $\begin{array}{c}-0.054 \\
(0.045)\end{array}$ & $\begin{array}{l}-0.025 \\
(0.035)\end{array}$ & $\begin{array}{l}-0.067 \\
(0.062)\end{array}$ & $\begin{array}{l}-0.031 \\
(0.028)\end{array}$ & & & & \\
\hline Sauvignon Blanc & & & & & $\begin{array}{c}0.136^{\star * *} \\
(0.050)\end{array}$ & $\begin{array}{c}0.111^{\star * *} \\
(0.034)\end{array}$ & $\begin{array}{c}0.086^{\star * *} \\
(0.032)\end{array}$ & $\begin{array}{c}0.126^{* * *} \\
(0.029)\end{array}$ \\
\hline Chardonnay & & & & & $\begin{array}{c}0.137^{* * *} \\
(0.049)\end{array}$ & $\begin{array}{c}0.133^{* * *} \\
(0.032)\end{array}$ & $\begin{array}{c}0.214^{* * *} \\
(0.050)\end{array}$ & $\begin{array}{c}0.197^{* * *} \\
(0.032)\end{array}$ \\
\hline Constant & $\begin{array}{c}-0.229^{\star *} \\
(0.107)\end{array}$ & $\begin{array}{l}-0.016 \\
(0.107)\end{array}$ & $\begin{array}{l}-0.057 \\
(0.079)\end{array}$ & $\begin{array}{c}-0.210^{\star *} \\
(0.094)\end{array}$ & $\begin{array}{c}-0.377 \\
(0.299)\end{array}$ & $\begin{array}{c}-0.054 \\
(0.244)\end{array}$ & $\begin{array}{l}0.659^{\star *} \\
(0.301)\end{array}$ & $\begin{array}{l}-0.122 \\
(0.195)\end{array}$ \\
\hline Observations & \multicolumn{4}{|c|}{2183} & \multicolumn{4}{|c|}{481} \\
\hline R-squared & 0.18 & 0.21 & 0.25 & 0.34 & 0.15 & 0.18 & 0.24 & 0.31 \\
\hline
\end{tabular}

$*, * *, * *$ denotes significance at $10 \%, 5 \%, 1 \%$.

aBootstrap standard errors in parentheses; Replications $=1000$.

${ }^{b}$ Robust standard errors in parentheses; OLS = ordinary least squares, included as reference.

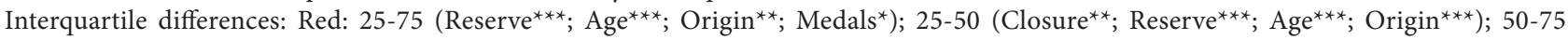

$\left(\right.$ Age $\left.^{* *}\right)$.

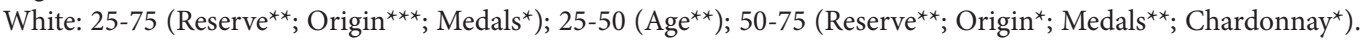


Table D3. France.

\begin{tabular}{|c|c|c|c|c|c|c|c|c|}
\hline & \multicolumn{4}{|c|}{ Red } & \multicolumn{4}{|c|}{ White } \\
\hline & 25-quantile ${ }^{a}$ & 50-quantile ${ }^{\mathrm{a}}$ & 75-quantile ${ }^{a}$ & OLS $^{\mathrm{b}}$ & 25-quantile ${ }^{a}$ & 50-quantile ${ }^{\mathrm{a}}$ & 75-quantile ${ }^{a}$ & $\mathrm{OLS}^{\mathrm{b}}$ \\
\hline Reserve & $\begin{array}{c}-0.190^{* *} \\
(0.082)\end{array}$ & $\begin{array}{c}-0.142^{\star *} \\
(0.059)\end{array}$ & $\begin{array}{c}-0.258^{* * *} \\
(0.075)\end{array}$ & $\begin{array}{c}-0.239^{* * *} \\
(0.054)\end{array}$ & $\begin{array}{c}-0.067^{* * *} \\
(0.024)\end{array}$ & $\begin{array}{c}-0.131^{\star *} \\
(0.053)\end{array}$ & $\begin{array}{l}-0.145 \\
(0.095)\end{array}$ & $\begin{array}{c}-0.113^{* * *} \\
(0.043)\end{array}$ \\
\hline Closure & $\begin{array}{c}0.169^{* * *} \\
(0.044)\end{array}$ & $\begin{array}{l}0.175^{\star *} \\
(0.076)\end{array}$ & $\begin{array}{l}0.251^{\star *} \\
(0.124)\end{array}$ & $\begin{array}{c}0.242^{* * *} \\
(0.052)\end{array}$ & $\begin{array}{c}0.118^{* * *} \\
(0.030)\end{array}$ & $\begin{array}{c}0.117^{\star * *} \\
(0.043)\end{array}$ & $\begin{array}{c}0.047 \\
(0.063)\end{array}$ & $\begin{array}{c}0.128^{* * *} \\
(0.037)\end{array}$ \\
\hline Wine origin & $\begin{array}{l}0.07^{\star *} \\
(0.032)\end{array}$ & $\begin{array}{l}0.092^{\star *} \\
(0.039)\end{array}$ & $\begin{array}{c}0.093 \\
(0.079)\end{array}$ & $0.035(0.037)$ & $\begin{array}{l}-0.011 \\
(0.033)\end{array}$ & $\begin{array}{c}-0.028 \\
(0.060)\end{array}$ & $\begin{array}{c}0.052 \\
(0.041)\end{array}$ & $\begin{array}{c}0.022 \\
(0.029)\end{array}$ \\
\hline Age & $\begin{array}{c}0.091^{\star * *} \\
(0.008)\end{array}$ & $\begin{array}{c}0.111^{\star * *} \\
(0.005)\end{array}$ & $\begin{array}{c}0.121^{\star * *} \\
(0.008)\end{array}$ & $\begin{array}{c}0.097^{\star * *} \\
(0.006)\end{array}$ & $\begin{array}{c}0.074^{\star * *} \\
(0.007)\end{array}$ & $\begin{array}{c}0.080^{* * *} \\
(0.011)\end{array}$ & $\begin{array}{c}0.104^{\star * *} \\
(0.014)\end{array}$ & $\begin{array}{c}0.088^{* * *} \\
(0.008)\end{array}$ \\
\hline Awards or medals & $\begin{array}{c}0.065^{\star * *} \\
(0.015)\end{array}$ & $\begin{array}{c}0.067^{\star * *} \\
(0.024)\end{array}$ & $\begin{array}{c}0.119^{\star * *} \\
(0.027)\end{array}$ & $\begin{array}{c}0.123^{\star * *} \\
(0.021)\end{array}$ & $\begin{array}{c}0.057^{\star * *} \\
(0.022)\end{array}$ & $\begin{array}{c}0.067^{\star * *} \\
(0.015)\end{array}$ & $\begin{array}{l}0.072^{\star} \\
(0.039)\end{array}$ & $\begin{array}{c}0.074^{\star * *} \\
(0.020)\end{array}$ \\
\hline AlcCont & $\begin{array}{c}0.061^{\star * *} \\
(0.013)\end{array}$ & $\begin{array}{c}0.078^{\star * *} \\
(0.019)\end{array}$ & $\begin{array}{c}0.093^{* * *} \\
(0.018)\end{array}$ & $\begin{array}{c}0.068^{* * *} \\
(0.013)\end{array}$ & $\begin{array}{c}0.100^{\star * *} \\
(0.012)\end{array}$ & $\begin{array}{c}0.126^{\star * *} \\
(0.015)\end{array}$ & $\begin{array}{c}0.141^{\star * *} \\
(0.027)\end{array}$ & $\begin{array}{c}0.119^{* * *} \\
(0.014)\end{array}$ \\
\hline Blend & $\begin{array}{c}-0.142^{\star * *} \\
(0.034)\end{array}$ & $\begin{array}{c}-0.179^{\star * *} \\
(0.036)\end{array}$ & $\begin{array}{c}-0.237^{* * *} \\
(0.045)\end{array}$ & $\begin{array}{c}-0.1666^{* * *} \\
(0.023)\end{array}$ & $\begin{array}{l}-0.042^{\star} \\
(0.023)\end{array}$ & $\begin{array}{l}-0.050^{*} \\
(0.027)\end{array}$ & $\begin{array}{c}-0.002 \\
(0.042)\end{array}$ & $\begin{array}{l}-0.009 \\
(0.023)\end{array}$ \\
\hline Cabernet Sauvignon & $\begin{array}{c}-0.162 \\
(0.126)\end{array}$ & $\begin{array}{c}-0.288^{\star *} \\
(0.027)\end{array}$ & $\begin{array}{c}-0.099 \\
(0.240)\end{array}$ & $\begin{array}{l}-0.169 \\
(0.109)\end{array}$ & & & & \\
\hline Syrah & $\begin{array}{c}0.096^{* * *} \\
(0.024)\end{array}$ & $\begin{array}{l}0.071^{\star} \\
(0.039)\end{array}$ & $\begin{array}{c}0.003 \\
(0.041)\end{array}$ & $\begin{array}{l}0.050^{*} \\
(0.029)\end{array}$ & & & & \\
\hline Sauvignon Blanc & & & & & $\begin{array}{l}0.057^{\star} \\
(0.031)\end{array}$ & $\begin{array}{c}0.005 \\
(0.041)\end{array}$ & $\begin{array}{c}-0.075^{\star *} \\
(0.031)\end{array}$ & $\begin{array}{l}-0.012 \\
(0.027)\end{array}$ \\
\hline Chardonnay & & & & & $\begin{array}{c}0.137^{\star * *} \\
(0.027)\end{array}$ & $\begin{array}{c}0.170^{\star * *} \\
(0.034)\end{array}$ & $\begin{array}{c}0.188^{\star * *} \\
(0.047)\end{array}$ & $\begin{array}{c}0.174^{\star * *} \\
(0.026)\end{array}$ \\
\hline Constant & $\begin{array}{l}-0.218 \\
(0.194)\end{array}$ & $\begin{array}{l}-0.357 \\
(0.268)\end{array}$ & $\begin{array}{l}-0.484^{*} \\
(0.275)\end{array}$ & $\begin{array}{l}-0.185 \\
(0.194)\end{array}$ & $\begin{array}{c}-0.554^{\star * *} \\
(0.169)\end{array}$ & $\begin{array}{c}-0.775^{\star * *} \\
(0.197)\end{array}$ & $\begin{array}{c}-0.891^{\star * *} \\
(0.334)\end{array}$ & $\begin{array}{c}-0.741^{\star * *} \\
(0.183)\end{array}$ \\
\hline Observations & \multicolumn{4}{|c|}{1330} & \multicolumn{4}{|c|}{764} \\
\hline R-squared & 0.18 & 0.21 & 0.22 & 0.32 & 0.25 & 0.26 & 0.27 & 0.43 \\
\hline
\end{tabular}

$*, * *,{ }^{* *}$ denotes significance at $10 \%, 5 \%, 1 \%$.

aBootstrap standard errors in parentheses; Replications $=1000$.

${ }^{b}$ Robust standard errors in parentheses; OLS = ordinary least squares, included as reference.

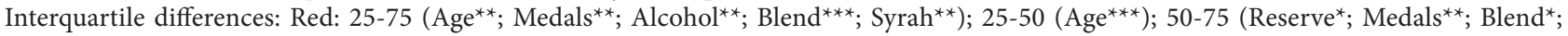
Syrah*).

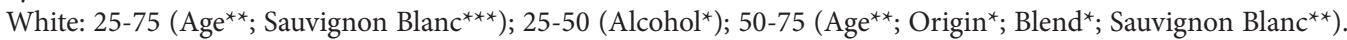


Table D4. Italy.

\begin{tabular}{|c|c|c|c|c|c|c|c|c|}
\hline & \multicolumn{4}{|c|}{ Red } & \multicolumn{4}{|c|}{ White } \\
\hline & 25-quantile ${ }^{a}$ & 50-quantile ${ }^{a}$ & 75-quantile & $\mathrm{OLS}^{\mathrm{b}}$ & 25-quantile ${ }^{a}$ & 50-quantile ${ }^{\mathrm{a}}$ & 75-quantile ${ }^{a}$ & $\mathrm{OLS}^{\mathrm{b}}$ \\
\hline Reserve & $\begin{array}{c}0.006 \\
(0.021)\end{array}$ & $\begin{array}{l}-0.008 \\
(0.031)\end{array}$ & $\begin{array}{l}-0.016 \\
(0.022)\end{array}$ & $\begin{array}{l}-0.004 \\
(0.021)\end{array}$ & $\begin{array}{c}0.039 \\
(0.043)\end{array}$ & $\begin{array}{c}0.019 \\
(0.041)\end{array}$ & $\begin{array}{l}-0.045 \\
(0.043)\end{array}$ & $\begin{array}{c}0.001 \\
(0.031)\end{array}$ \\
\hline Closure & $\begin{array}{c}-0.174^{* *} \\
(0.086)\end{array}$ & $\begin{array}{l}-0.099 \\
(0.064)\end{array}$ & $\begin{array}{c}-0.031 \\
(0.108)\end{array}$ & $\begin{array}{l}-0.063 \\
(0.056)\end{array}$ & $\begin{array}{l}0.107^{\star *} \\
(0.051)\end{array}$ & $\begin{array}{c}0.128^{* * *} \\
(0.044)\end{array}$ & $\begin{array}{l}0.292^{\star *} \\
(0.129)\end{array}$ & $\begin{array}{c}0.148^{* * *} \\
(0.047)\end{array}$ \\
\hline Wine origin & $\begin{array}{c}-0.164^{* * *} \\
(0.028)\end{array}$ & $\begin{array}{c}-0.258^{\star * *} \\
(0.023)\end{array}$ & $\begin{array}{c}-0.356^{* * *} \\
(0.049)\end{array}$ & $\begin{array}{c}-0.270^{* * *} \\
(0.021)\end{array}$ & $\begin{array}{c}-0.185^{* * *} \\
(0.019)\end{array}$ & $\begin{array}{c}-0.241^{* * *} \\
(0.029)\end{array}$ & $\begin{array}{c}-0.331^{* * *} \\
(0.034)\end{array}$ & $\begin{array}{c}-0.269^{* * *} \\
(0.022)\end{array}$ \\
\hline Age & $\begin{array}{c}0.060^{\star * *} \\
(0.004)\end{array}$ & $\begin{array}{c}0.066^{\star * *} \\
(0.005)\end{array}$ & $\begin{array}{c}0.073^{\star * *} \\
(0.006)\end{array}$ & $\begin{array}{c}0.058^{\star * *} \\
(0.005)\end{array}$ & $\begin{array}{c}0.057^{\star * *} \\
(0.006)\end{array}$ & $\begin{array}{c}0.080^{\star * *} \\
(0.005)\end{array}$ & $\begin{array}{c}0.099^{* * *} \\
(0.008)\end{array}$ & $\begin{array}{c}0.062^{\star * *} \\
(0.007)\end{array}$ \\
\hline Awards or medals & $\begin{array}{c}0.254^{\star * *} \\
(0.087)\end{array}$ & $\begin{array}{c}0.197^{* * *} \\
(0.071)\end{array}$ & $\begin{array}{l}0.176^{*} \\
(0.105)\end{array}$ & $\begin{array}{c}0.185^{\star * *} \\
(0.056)\end{array}$ & $\begin{array}{l}-0.055 \\
(0.045)\end{array}$ & $\begin{array}{l}-0.056 \\
(0.041)\end{array}$ & $\begin{array}{l}-0.209 \\
(0.131)\end{array}$ & $\begin{array}{l}-0.036 \\
(0.048)\end{array}$ \\
\hline AlcCont & $\begin{array}{c}0.080^{\star * *} \\
(0.007)\end{array}$ & $\begin{array}{c}0.081^{\star * *} \\
(0.008)\end{array}$ & $\begin{array}{c}0.085^{\star * *} \\
(0.015)\end{array}$ & $\begin{array}{c}0.097^{\star * *} \\
(0.008)\end{array}$ & $\begin{array}{c}0.095^{\star * *} \\
(0.010)\end{array}$ & $\begin{array}{c}0.098^{\star * *} \\
(0.009)\end{array}$ & $\begin{array}{c}0.111^{\star * *} \\
(0.017)\end{array}$ & $\begin{array}{c}0.118^{\star * *} \\
(0.010)\end{array}$ \\
\hline Blend & $\begin{array}{c}-0.076^{* * *} \\
(0.012)\end{array}$ & $\begin{array}{c}-0.082^{\star * *} \\
(0.014)\end{array}$ & $\begin{array}{c}-0.086^{* * *} \\
(0.015)\end{array}$ & $\begin{array}{c}-0.103^{* * *} \\
(0.013)\end{array}$ & $\begin{array}{c}-0.060^{* * *} \\
(0.010)\end{array}$ & $\begin{array}{c}-0.062^{* * *} \\
(0.020)\end{array}$ & $\begin{array}{c}-0.075^{\star * *} \\
(0.027)\end{array}$ & $\begin{array}{c}-0.102^{\star * *} \\
(0.017)\end{array}$ \\
\hline Cabernet Sauvignon & $\begin{array}{c}-0.100 \\
(0.073)\end{array}$ & $\begin{array}{c}-0.076 \\
(0.067)\end{array}$ & $\begin{array}{c}-0.086 \\
(0.054)\end{array}$ & $\begin{array}{c}-0.070 \\
(0.046)\end{array}$ & & & & \\
\hline Syrah & $\begin{array}{l}-0.059^{*} \\
(0.033)\end{array}$ & $\begin{array}{c}-0.100^{*} \\
(0.054)\end{array}$ & $\begin{array}{c}0.050 \\
(0.103)\end{array}$ & $\begin{array}{c}-0.017^{* *} \\
(0.045)\end{array}$ & & & & \\
\hline Sauvignon Blanc & & & & & $\begin{array}{c}0.011 \\
(0.021)\end{array}$ & $\begin{array}{c}0.005 \\
(0.025)\end{array}$ & $\begin{array}{c}-0.095^{\star * *} \\
(0.022)\end{array}$ & $\begin{array}{c}-0.072^{\star * *} \\
(0.022)\end{array}$ \\
\hline Chardonnay & & & & & $\begin{array}{c}0.102^{\star * *} \\
(0.022)\end{array}$ & $\begin{array}{c}0.051 \\
(0.034)\end{array}$ & $\begin{array}{c}-0.027 \\
(0.036)\end{array}$ & $\begin{array}{c}0.015 \\
(0.024)\end{array}$ \\
\hline Constant & $\begin{array}{l}-0.130 \\
(0.092)\end{array}$ & $\begin{array}{c}0.046 \\
(0.095)\end{array}$ & $\begin{array}{c}0.182 \\
(0.184)\end{array}$ & $\begin{array}{l}-0.103 \\
(0.102)\end{array}$ & $\begin{array}{l}-0.225^{\star} \\
(0.133)\end{array}$ & $\begin{array}{c}-0.195^{\star} \\
(0.103)\end{array}$ & $\begin{array}{l}-0.193 \\
(0.216)\end{array}$ & $\begin{array}{c}-0.337^{* * *} \\
(0.124)\end{array}$ \\
\hline Observations & \multicolumn{4}{|c|}{1557} & \multicolumn{4}{|c|}{1246} \\
\hline R-squared & 0.24 & 0.25 & 0.22 & 0.38 & 0.29 & 0.34 & 0.38 & \\
\hline
\end{tabular}

$*, * *, * *$ denotes significance at $10 \%, 5 \%, 1 \%$.

aBootstrap standard errors in parentheses; Replications $=1000$.

${ }^{b}$ Robust standard errors in parentheses; OLS = ordinary least squares, included as reference.

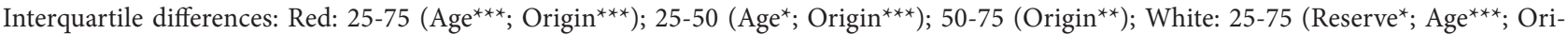

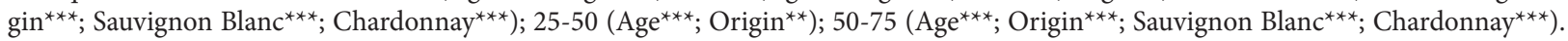

